\title{
Concept Paper on the Efficacies and Twist of Human Resource Management Future with the New Era of Coronavirus Pandemic (Covid-19) for Organizational and Institutional Action
}

\author{
Abdul Kahar Adam ${ }^{1}$ \\ Isaac Yaw Manu ${ }^{2}$ \\ ${ }^{1}$ University of Education, Winneba, School of Business, \\ Department of Management Sciences, Central Region, Ghana \\ ${ }^{2}$ Division Human Resource, University of Education, Winneba, Ghana. \\ akadam@uew.edu.gh \\ aka11@live.co.uk
}

\begin{abstract}
The essence of this paper is eminent to advance the study of Human Resource Management (HRM) in the profound new directions that has been introduced due to the covid-19 pandemic. This particular review elaborates on the following such as: Challenges Caused by Covid-19 to HRM Principles and Practice, HRM Outlook within Continents in this Coronavirus Pandemic, How Information Technology can still grow HRM in new Practices, The Case of HRM Practice in Developing World with Covid-19, How Both National and International HRM Practice is portrayed with Covid-19, Moving Forward with HRM Practice and Covid-19, and Organizational and Institutional Challenges and Demands in HRM Policies and Law. The general conclusion with this new Human Resource Management is associated with massive application of technology that Human Resource Management practices in various organizational operations and ways of doing things in the traditional HRM way has changed. Many of the roles are been performed remotely using internet and relevant HRM laws, applications and policies to deliver in managing work and the people. This is eminent for HRM practitioners and professionals to further educate and train themselves in this covid-19 era to avert themselves with the new principles instituted by organizations and governments in the area of HRM of activities and people. In this review the HRM is been twisted and thereby its efficacies are challenged which is why this new study is important to the practitioners and professionals to adapt and/or adopt.
\end{abstract}

Keywords: Human Resource Management, HRM efficacies, covid-19 HRM, Internet HRM, Remote HRM

\section{How to Cite:}

Adam, A. K. (2021). Concept paper on the efficacies and twist of human resource management future with the new era of coronavirus pandemic (covid-19) for organisational and institutional action. International Journal of Business, Management and Economics, 2(4). 288 - 321. DOI: https://doi.org/10.47747/ijbme.v2i4.455 


\section{Introduction}

HRM was developed out of labour relations and personnel management in order to make employees happier and more satisfied. With this contention some had the view that HRM was to serve the purpose and aim of only the organization but whatever the issue, HRM was established to boast the morale of employees through employer-employee good relationship. With the coronavirus pandemic has posed a lot of new challenges to HRM in organizational application and practice hence, the way organization recruitment of staff and training them will have to change. The kind of qualities and experience of potential applicants will be affected in one way or the other.

HRM is there to improve the efficiency and effectiveness of organizational objectives through employer-employee satisfaction. In fact, employer-employee relationship will be affected in one way or the other without much physical interactions. This means HRM will now be termed Information Technology Human Resource Management (ITHRM) driven by the coronavirus pandemic. But it is clear that this study is a new phenomenon and so therefore, there are no many peer reviewed journal articles to this context of the submission, although, many featured articles are available and are been considered in the contents of this review.

The purpose of this review and its sub-headings is to dissect the challenges that HRM was already facing in organizational practice and how useful ITHRM can be with this coronavirus pandemic. Its aim is to point out clearly theories that are now challenged in the practice of HRM and the way forward for HRM professionals and practitioners. The objective is to establish new way of studying HRM since human resource management in every organization is been challenged and ways of practicing HRM has changed.

The initial purpose and mission of Human Resource Management (HRM) has been challenged by the coronavirus pandemic. HRM is about people management in the best way to harness their potentials for the achievement of organizational goals. With the covid-19 pandemic, raised awareness to organisations to be robust as to how to survive with HR management as a department that do recruitment and selection of the workforce. Now, due to social distancing been the norm and practice per the covid-19 preventive measures/cautions placed a very disruptive systems to the operation of HRM practice. Most of these challenges has to do with the impact of covid-19 on human resource management by avoiding generalizations (Aitken-Fox et al., 2020).

Aitken-Fox et al., (2020) stated that many organisations have for the first time started using remote working and that Human Resource Professionals as from now have to improvise their daily work. They are of the view that with the covid-19, there comes with a new norm in human resource management practice, which can also be termed flexible in nature. The impact of working practices and welfare of employees are very important to establish in HRM contexts. Although there are countries and institutional nuances and differences at stake. According to a publication with London School of Economics, stated that a research survey carried out with interviews of managers and officers in people management positions first showed an ironic and an expected outcome. For instance, whilst during this pandemic many industries faced difficult and challenging times with negative reports whiles others are positively affected (Aitken-Fox et al., 2020). Some of these areas that are experiencing positive responses in Australia are public administration, healthcare and social assistance, 
mining, finance and insurance. Even though, the respondents are now working remotely without making their positions vacant and working hard by retaining their workforce without any relying on the government subsidies or support. Whiles others freeze hiring of workforce others too are adding more of new recruits to enhance productivity.

Another response indicates that whiles many are predicting organisations increasing their work remotely in the near future, it is not a clear picture that this would be the case. This means that some organizations are not all that troubled in terms of human resource management responsibilities are concerned. By far, that some companies are yet to make decisions about their remote working commitments, as they do not know yet how this remote working system will affect staff performance in terms of productivity. Hence, it is noted that organisations are still doubting and debating as to whether there will be any changes to remote working or not going beyond this covid-19 pandemic.

The third report deduced from the interview is that matters that bothers on the people management topics as the covid-19 has changed many work practices. Therefore, this means that going forward the HRM practitioners will have to stay alert and be responsive to the changing needs and demands of this pandemic. The main factor identified in this exercise is about effects of compliance to the legal systems that needs to be changed to accommodate the pandemic work situations together with internal procedures and policies such as working conditions with flexibility. In this case, it is not all organisations that may need to side-step or ignore certain laws affecting employment in the national context but it has to balance with relevance. Since, work practices and engagements always start and end with HRM professionals and practitioners, they feel valuable during this pandemic since they have to direct and command a lot of workforce to stay in production and customer services. The following are heighted in this survey by respondents that:

- staff to have technology system and setups that are functioning well at home

- provide good supervision

- ensuring effective communication

- productivity and performance management

- support and employee engagement

- redesigning policies for remote working conditions, and

- realigning and designing working conditions and employee benefits

The above shows that the Human Resource Management Professionals and Practitioners roles have increased tremendously and significantly as many organisations are trying to adapt to situations within national context during this covid-19 pandemic.

Further responds indicated that employees' safety and welfare is paramount and crucial in nature. Remote working does not include everybody but only suitable for those it affects directly and situational demands. With the issue of full lock-downs and partial lock-downs across towns and cities calls for employee safety and welfare were important. This will encourage spatial arrangements and demands from the family which calls for new and different HRM expertise to be developed and applied in the organisations.

Lastly, but not the least, this pandemic have made employees and other people to show good behaviour by recognizing and helping one another for business continuity as they show 
willingness to collaborate with each other to effect changes. Employees have shown willingness to be flexible and adaptable and follow the necessary changes without any agitation or strike or demonstration. They also showed willingness to learn and grow quickly which enables many organisations to effectively manage the rapid changes. Most organisations could not have smooth working relationships and decision-making towards remote working since some managers have perceived perception that it will affect production and performance. With all these challenges calls for Human Resource Managers and professionals to be more experts in giving advice to other functional managers as to how to effectively manage remote workforce performance. But where there is no trust micromanagement is introduced if they are invisible.

\section{Literature Review}

\section{Moving Forward with HRM Practice and Covid-19}

Since the covid-19 pandemic is not over yet, it makes it difficult for HR Managers and Professionals to plan their work at once but rather have to think ahead of the covid-19 now that it seems it has come to stay. Hence, moving forward with HRM practice and covid-19 is eminent. Collington (2020), stated that in the past 30 years, HRM functions went through changes, that is, from post-personnel management in relations to staff discipline, welfare, training and development when the workforce was seen as the greatest asset compared to the current human capital management ( 3 box Ulrich++ model). That HRM profession was seen as key responsibility and function of influencer for multiple stakeholders but it has now become cost control and the protection of shareholder returns. In this view, HRM role has engulfed the changes in economics and business and it is now time for the HRM professionals to reassert their responsibilities and functions that will create sustainability for the workforce and the organization (Collington, 2020). It is also established that the covid-19 pandemic creates a new direction regarding society and the people at work (workforce). The consequence and causes of this are that companies and organisations never waited for any government intervention and support. It is reported that about 20 million Americans lost their jobs and about $1 / 3^{\text {rd }}$ of all UK youth, under 25 years old lost their jobs due to retail and manufacturing companies been shut down or closed. Therefore, it is now recommended that organisations has to prioritise their needs of the employees, customers, shareholders and the communities in which they conduct their businesses (Collington, 2020).

Moreover, front-line workers had to keep business moving on during the pandemic who are largely the lower paid in the society. The question was how countries manage the needs of their citizens during the pandemic? Have the countries got the necessary resources and industries needed or the supply chain is overly relied upon? The coronavirus can be contracted, tested, and treated but the treatments available are being affected by role and race of people and the economic status. Below for example is USA claim by jobless people and that represent a total claim of unemployment weekly in 2020. 


\section{US jobless claims at record high \\ Weekly total of unemployment claims in 2020}

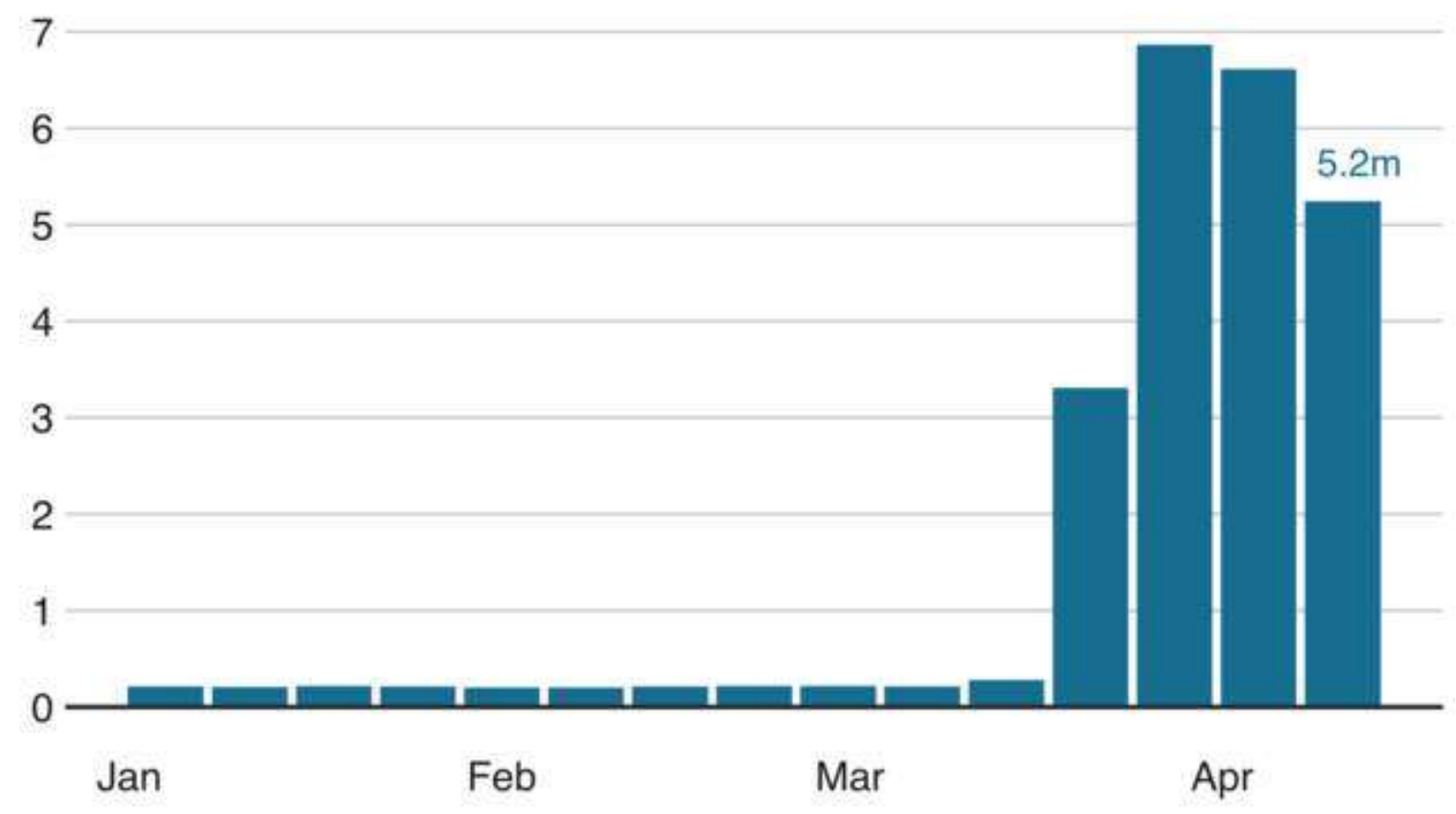

Source: US Bureau of Labor Statistics

The above shows that only in April 2020, the unemployment claims arose very high which actual means that due to the lock down many people on part-time jobs could not work and also those on contracts have been affected too.

\section{HRM Outlook within Continents in this Coronavirus Pandemic}

The coronavirus pandemic has brought about some positives across continents such as people are seen supporting each other and pulling together. For instance, millions of volunteers signed and supporting National Health Service (NHS) in the United Kingdom (UK) together with school technicians used 3D printers and made face shields. The pandemic brought about endless creativity and innovations in the pursuit of sense of belongingness and purposefulness. Most factories are over working to meet demand needs; people changing job roles to earn new income as they lose their original jobs. Working from home was not an option for majority of company's employees but due to the covid-19 pandemic many people now work flexibly from home performing many roles. It brought about love everywhere among employees and people now care for one another as human beings facing the same challenges. This pandemic brought a sense of humour. Above all, it has taught people ways of living significantly with positive effects like the environmental pollution is reduced 
drastically. Rushing hours by employees to go to work has somewhat reduced. Families stayed together for a longer period of time.

There are more hope looking into the future with the covid-19 pandemic. It does appear as a catalyst for a better life in the future with great awareness towards any further crisis. According to Collington (2020) stated that since 1947, the members of the Atomic Scientist Bulletin predicted the world with regards to the global issues such as pandemics that have negative effects on humanity in which they summarized the total risk using a clock based on the lifespan of human beings on the planet. Below is the clock with appropriate data.

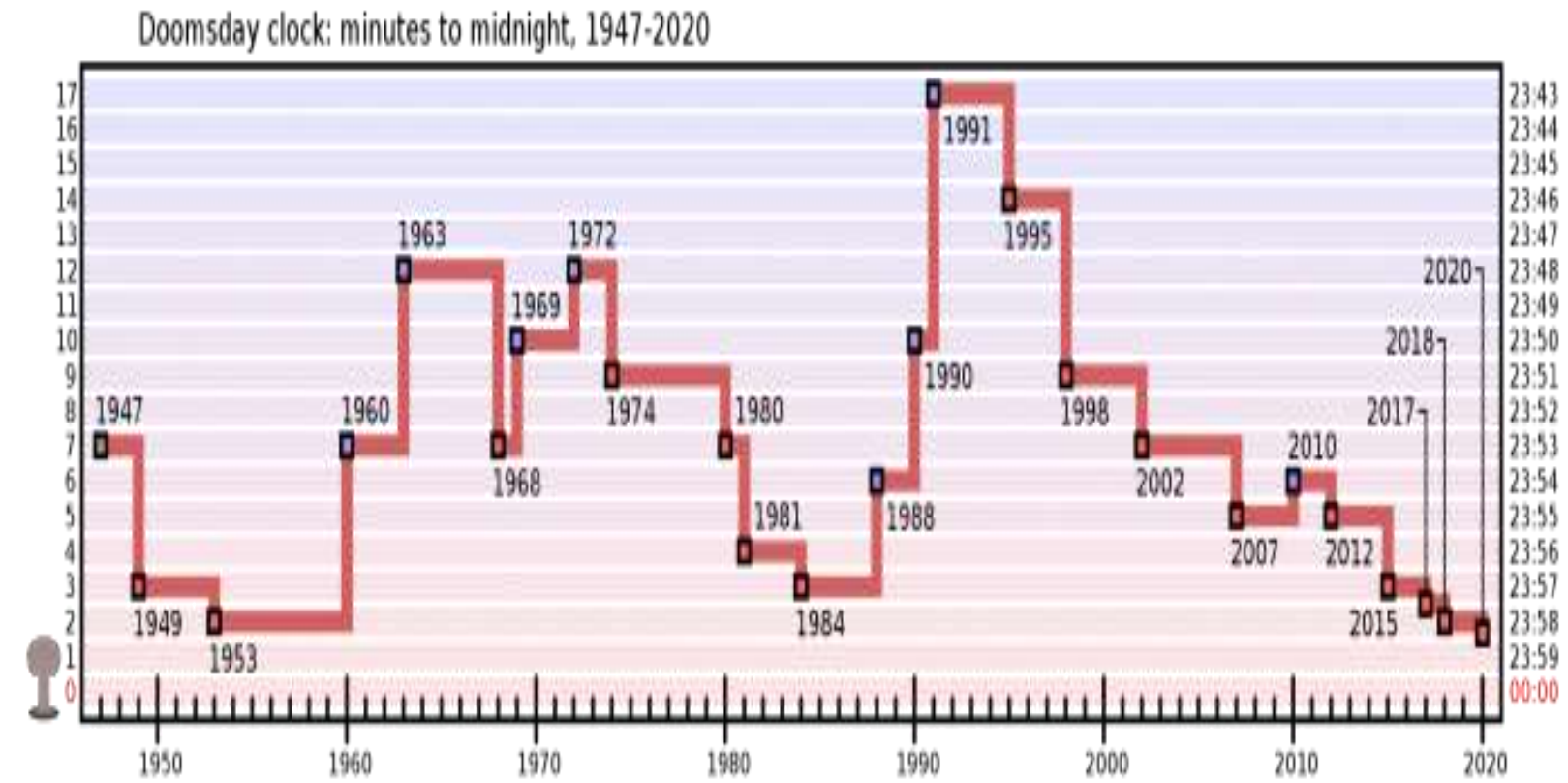

Source: Bulletin of the Atomic Scientists

More issues that are troubling the progress of human beings in the economic sense has to do with the experiment of neoliberalisation model. This model stands for free market values and competition where there is easy movement of capital and trade. Ironically, the introduction of this model is seen to have some effects on human progress as follows:

It increases the gap between the poor and the rich, and also, increases extreme income inequalities in the society. The current richest man in the world is Jeff Bezos, whose fortune grow up to $£ 140$ billion in 2020 due to the consequence of coronavirus pandemic (Collington, 2020 ). That in 2010 , the richest people representing only 10 had a total wealth of $\$ 296.8$ billion compared to an increase of $\$ 822.5$ billion in 2020. It is estimated that about 26 of the world richest people own half of the world wealth of the global population. The following diagrams depicts the realities of the world wealth distribution and ownership of wealth. 


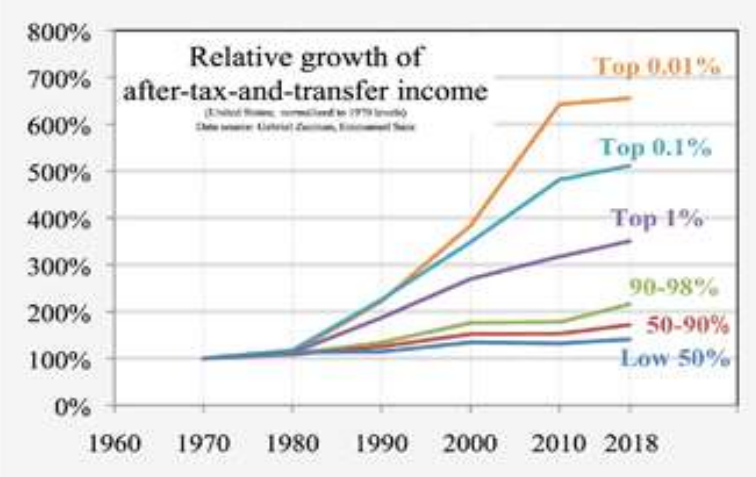

Data source: Gabriel Zucman, Emmanuel Saez

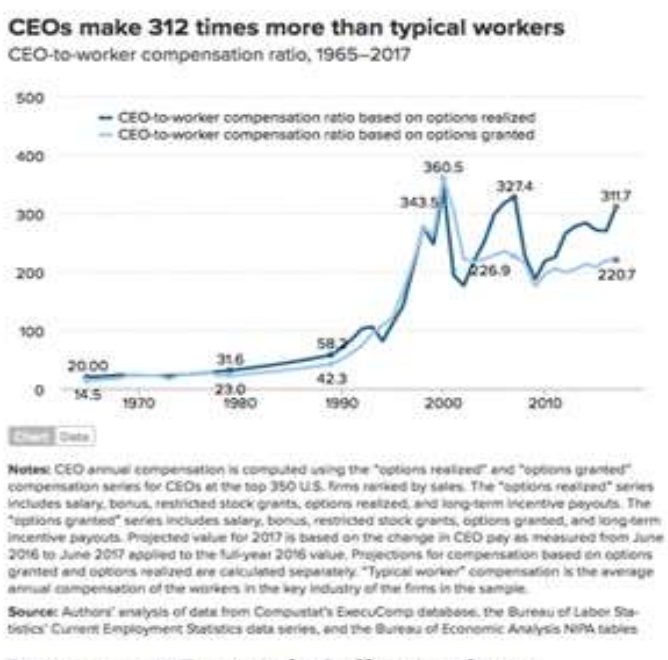

Data source: Economic Policy Institute

The theory behind the neoliberalisation assumed that everybody gets the benefits from topdown approach of growing economies, but the realities in other parts of the work especially in the African continent proves opposite. Whiles employees' salaries and wages are stagnated, many CEOs compensation packages and salaries are sky rocketing just as in 1975, about 500 CEOs compensation packages was 25 times their workers and in 2017 it went up to a ratio of 312 high. The pay and benefits disparities are there everywhere in the world. In the USA and $\mathrm{EU}$, the poor working class continues to grow high and it is much worst in the African countries where data and statistics are scanty or unavailable to analyze. The bottom line of these narratives is that there is no true top down effect. Below is a diagram that shows the poor working-class data in EU.

Share of EU working poor on the rise

Employed people at risk of poverty, $\%$

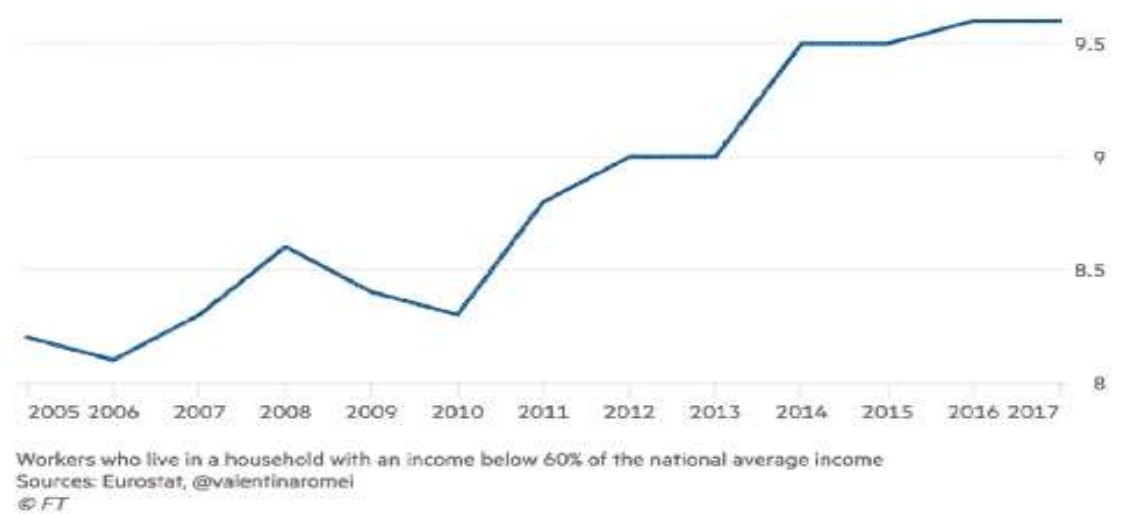

Published by: 
It is basic that businesses determine their success and achievements through the growth in revenue, shareholder returns and profits. The assumptions that countries have against their growth is Gross Domestic Product (GDP) which is measured as creating more wealth through taxes for public good. Whereas the global GDP is suggested to grow in doubles within the next 25 years whereby the social prices and environmental conditions for this growth is predicted to be too high. Below diagram is the Gross Domestic Product (GDP) in Europe.

\section{Gross domestic product (trillion 2005 USD PPP)}

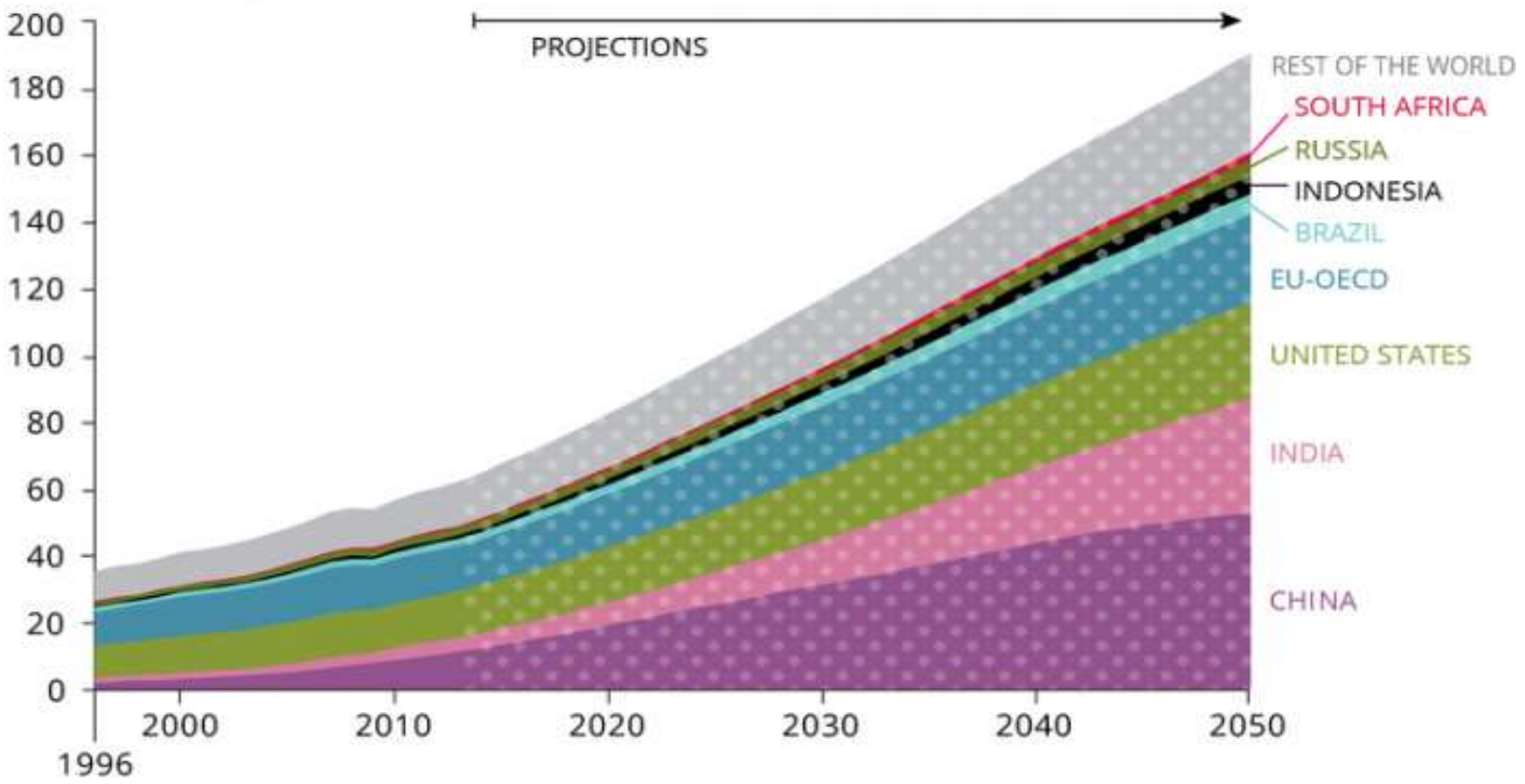

Source: European Environment Agency

The picture in the above diagram depicts that businesses financialization has been unchecked progressively for the past 40 years, though, it only protects the interest of the shareholders returns. In the United States, $25 \%$ of all corporate profits is taking and pay towards the fast growth which rather provides very high interest investment. The financial sector of the USA accounts for only $4 \%$ of jobs as against GDP of $7 \%$. The system only redirect money away from workers, Research and Development, and, the communities. Below diagram represents dividends and buybacks by corporations. 


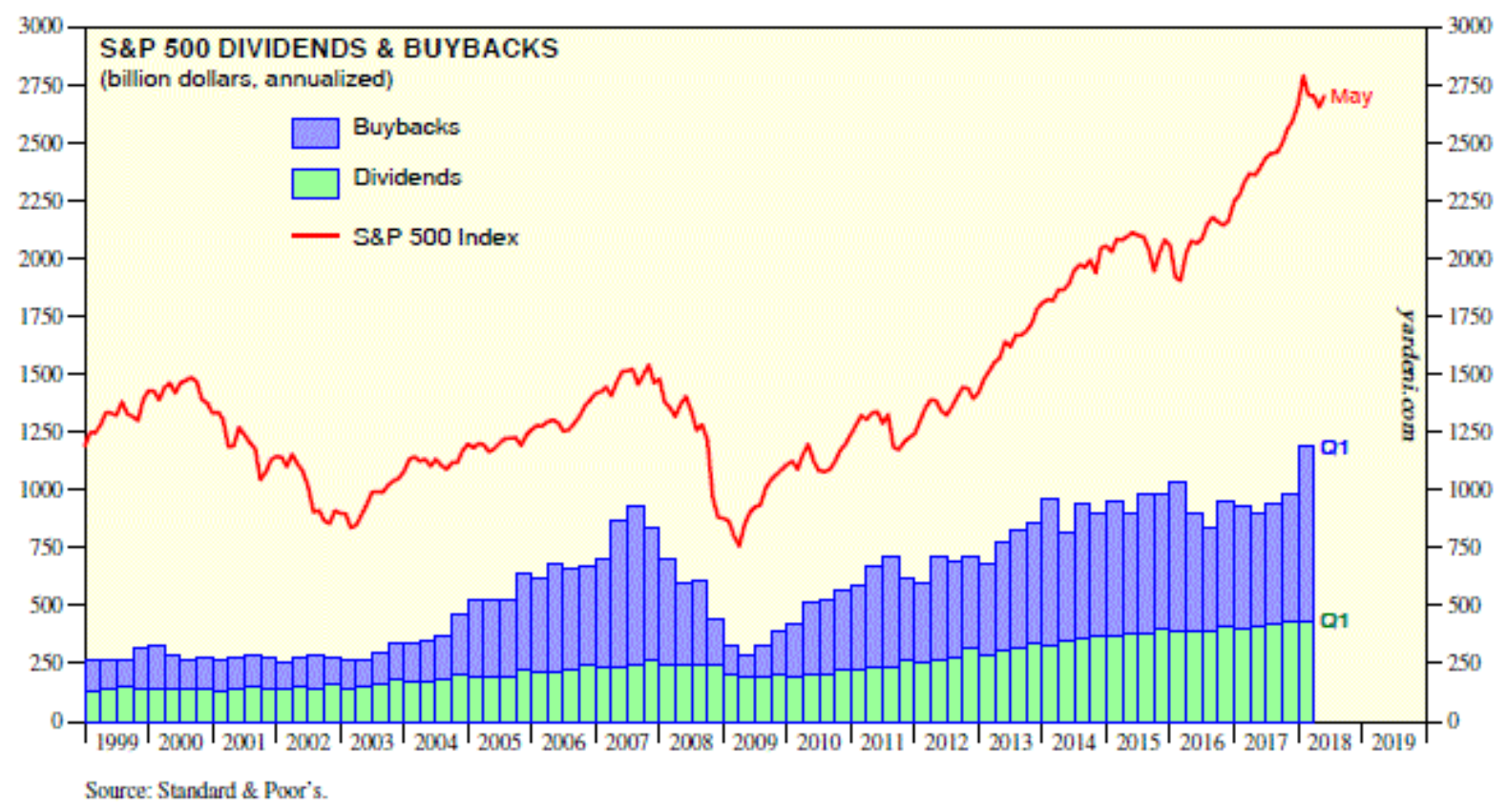

From the diagram above, CEOs compensation packages are overly linked to share prices with a shift to stock related compensation which was about $28 \%$ to $51 \%$ in 2009 and 2018 respectively. The facts show that when CEOs compensation is proportioned directly linked to the stock prices then it makes situations worse from medium term to long term performance of the businesses. Below diagram shows clearly the CEOs pay in 2018 fiscal year as discussed.

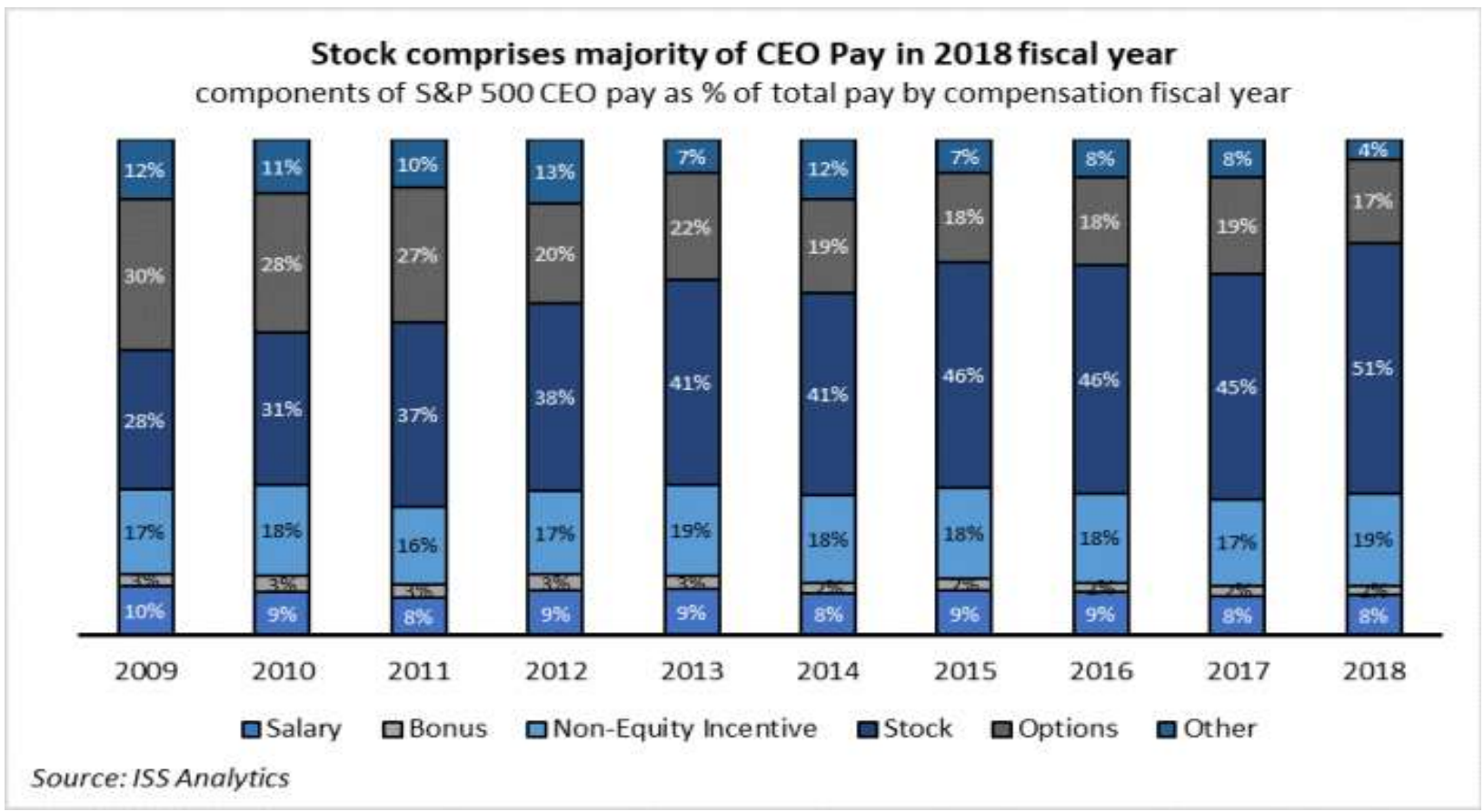

Published by: 
Studies of neoliberalisation show that privatization of public sector services to be a good move but the public sector is rather demonized and made inefficient by media and through degraded or reduced funding. Thereby deregulated those companies and sold off as a piecemeal to private entities with the intention to provide better services to the society but they rather serve and providing shareholders returns as priority. What is seen as common is the positives and benefits that the wealthy class enjoy through their clubs, conferences, meetings, joint ventures, mergers, and creation of wealthy society as status are all the effective ways and good traits of society where the expectation is wealth sharing, supporting one another, and collaborating among themselves. Due to the rise of wealthy class globally, in 1980s their influence caused the reduction of working-class where power was centered and the laws affecting governments where changed to suit the rich. This has been the case globally ever since.

They lobby government to change laws to suit them more than the working-class. The situation caused here is that there is a gap between the reality of neolibaralization implementation and the theory where all is ignored by the advocate institutions. For instance, under the free market which underpins as good in this world through reduction of restrictions in the private sector and on trade but as soon as businesses goes wrong, they place it on something else. For example, they will say because of restrictive laws by government or the leaders or workers let the company down. This attitude was the main cause of the 2008 crash because of human greed in selling mortgages as sub-prime supported by false evaluations and poor credits. The irony is that governments have stepped in to support businesses during the global banking crises in 2008 and now this covid-19 pandemic which at normal times those companies would have refused government interference. Evidences show that global tax regulations haven't been favourable with globalization of those big corporations because many of the top big companies have evaded corporate taxes and by this many of them have moved their business to the poor countries where taxes are very low and/or negotiate themselves for tax havens and it is given by those poorer nations especially in African countries.

Collington, (2020) recommended that people with age up to 40 years now should never think that the way countries are being governed and run by leaders has been the only best way, that no, people made choices and so therefore new choices can be made the same way to tune to the current circumstances. This clearly shows that policies made 40 years ago has failed the world and therefore new ways of doing things and new systems are needed to pave the way forward.It is stated that this covid-19 pandemic could cause companies in the future fundamentally, a shift as to how they would be judge on the bases on how they supported and treated their people during the pandemic, a statement by Mark Carney (a retiring governor of the bank of England) made this in the Economist (Collington, 2020). The diagram below show the doughnut economics. 


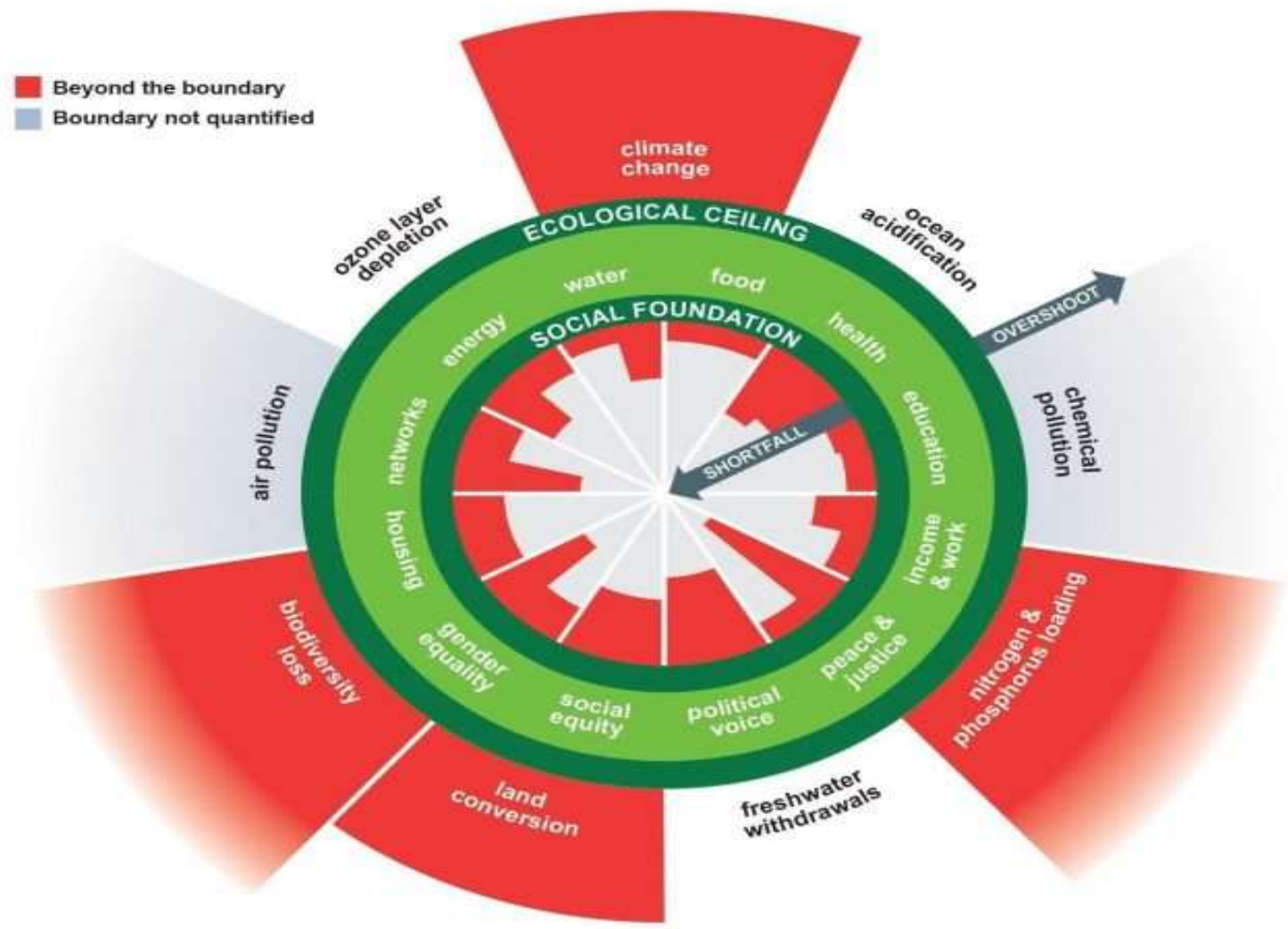

Source: Collington, (2020), Doughnut Economics

The above model consists of rings or circles, inner and outer. The inner circles are the resources we all need as it is sufficient for us to lead a good life such as; food, houses, clean water, energy, sanitation, education, democracy and healthcare. These are the deprived people living in the inner ring. Whereas the outer circle includes the earths environmental limits which rather goes beyond as the environment is been polluted and become dangerous to climate change such as, water pollution, ozone layer depletion, other distraction to living world, and loss of species. The portion between the two rings or circles is labelled ecologically safe and socially just space where people have to strive to live. Therefore, the purpose of economics in relation to the HRM is to help direct and support us to enter inside that space and live there permanently. Hence, people must focus their time and energy and make sure they live within the boundaries of the doughnut, which HRM professionals and practitioners must play a greater role as they manage and deal with people.

The distinction between HRM and Economics as studies show is that Economics lay the foundations of theories and models of how resources can be used beneficially whereby the HRM then deal with the people in order to effect those benefits by applying its principles and objectives.

Collington, (2020) concluded on the role of HRM of people and team from 2020 onwards as follows: 
- There is the need to establish refreshed roles where HRM practitioners and professionals will have to be challenging, brave, and working together to create new professional standard and better consistent systems by which company objectives and the people can grow.

- Also, there is the need to shape the organisations, its leaders, and by ensuring and directing the best way to work is a big responsibility on the shoulders of those practicing HRM to deliver.

- That the core role of the term 'People Team' is ensuring that the culture, values and the purpose and objectives of the organization are fully interconnected with the stakeholders such as a business model that create and distribute value to its consumers and customers, investors, employees, and also beneficial to the planet. Moreover, listening to the voice and contribution of employees as well as the advocates made towards company decisions. As such, shareholders or investors must be created and recognized towards the long-term benefits of the objectives of the organization.

- This coronavirus pandemic has enabled practitioners to identify people teams in HR management structures and a shift from few strategic relationships with top managers as the intermediary for the business and understands the situations within the layers from bottom staff to the executives.

- Communication and skills gaps for each level must be planned clearly to include career and flow of information.

- The people team must be experts in building career networks that broadens employees' opportunities that fits into the demands of the organization, the individual and the society they live in.

- The people team's role is to promote a new employee-employer paradigm relationship such as Commercial, Adult, and Partners (CAP). Commercial because we make business to work and flourish, Adult because we are all adults and hence, we communicate with mutual respect, this is how things are achieved working together. Partners because we are peers whatever the position of the organizational structure.

- People Team's role will build teamworking model and new leadership and also creating better employee wellbeing.

\section{Organisational and Institutional Challenges and Demands in HRM Policies and Law from Covid-19}

From the emergence of covid-19 has shaken the operations and existence of Organisations and Institutions and thereby a challenge for Human Resource Management professionals and practitioners to handle. Wright (2020) suggested that due to news and information about the coronavirus which at times seems contradictory and brought about confusion and anxiety to companies. The following are guidelines provided to support HRM practitioners and professionals:

- Follow directives and stay informed - that is prepare to listen to government broadcast about the coronavirus to enable HR managers to further implement within their organisaitons. 
- Prevention Practices must be followed - it is important to constantly remind the workforce to comply with the following general and basic practices for prevention and spread of the diseases.

a. Regularly and thoroughly wash your hands

b. When to sneeze or cough, cover your nose and face with either tissue or into your sleeve or handkerchief but not with bare hands.

c. Do not touch your eyes, mouth, and nose when you do not wash your hands or with sanitizer.

d. Constantly and routinely clean areas or surfaces that are touched at your workplace like countertops, workstations, and doorknobs.

It is advisable for employers to encourage these practices by providing soaps, tissues, and disinfectants and wipes throughout designated workspaces. Just as the following precautions:

- Get your temperature taken if you feel ill or if you are sick with fever do not come to work.

- And notify your supervisor or manager if you are sick and have to stay at home.

- If one has symptoms of acute respiratory illness, do not come to work and stay home until you are free of it.

- If any member of your household or yourself contracts the coronavirus, kindly inform your HR Manager or department where they may refer to CDC guidelines as to how to conduct a risk assessment against potential exposure.

There is the need for Sick Leave Policies to be reviewed by HR departments to be certain that they are in line with the public health directives and order, and are flexible. The HR Manager must make sure that the organizational polices conforms with any paid sick leave laws applicable to the employees. More importantly, employees who do not have paid sick leave or time would be reluctant to call in sick, hence, consider creating an interim public health emergency sick leave plan which will include paid sick leave or increase in sick leave pay of a category. It must be made clearly to staff that should incase one turn up to work and it is observed that the person has symptoms of illness that includes but not limited to wheezing, coughing, or other form or illness will be sent home and would be directed to go for medical checkup.

Even though, employers are mandated to request fitness-for-duty test and clearance daily at work and also from a doctor as it is eminent, but such test and clearance need to go through ADA's "job related and consistent with business necessity test." Fitness for duty test and clearance purpose it to determine whether an employee reporting to work can work effectively and efficiently without any health treat or substance abuse such as drinking and drugs and/or whether a staff who has been off sick for some time can return to work without jeopardizing others as threat. This one is normally done by a doctor with a confidential report to the employer.

In the USA, the House of Representatives has passed the Families First Coronavirus Response Act (HR6201) on 14 ${ }^{\text {th }}$ March, 2020 with emergency supplementary appropriation for the fiscal year ending $30^{\text {th }}$ September, 2020 which includes but not the least, The Paid Sick Days For Public Health Emergencies and Personal Family Care Act, and The Emergency Paid Leave Act of 2020.Additionally, the act again states that in the event of a public health 
emergency that each worker must be given additional paid sick time which is equivalent to what the worker would have earned regularly for a continuous 14 days period of work. And this must be enjoyed by employee as soon as the public health announces emergency without any reference to how long the employee has been employed. But it is only for existing employees where they can take the time as they schedule to take it and not the employer specified schedule. It is also added that if employer has over 50 or few numbers of employees, they may apply to the Secretary of Labour for reimbursement of such wages spent or lost.

The issue of hours of work and wages stated clearly that people who are not working are not entitled to this payment under the Fair Labour Standards Act; therefore, employers must review their contracts of employment, policies and practices that provide exceptions to the original rules, and collective bargaining agreements. Such payment by employer is due to the coronavirus pandemic which is in the best interest of the organisaiton. The issue of work interruption and business should alert employers to have their business plans against any eventuality or unexpected closure or working with few selected employees for a short period of time. Business policies that already have working home policy must be reviewed to ensure enough flexibility to comply with a potential quarantine or isolation. Employees whose work directly onsite may be relieved of their duties if the employer considers to modify their job titles, work requirements, duties and responsibilities, and give permission for remote work during this covid-19 pandemic. But remote workforce must be proactive and effective in nature and no or less disruption. At least the company intranet and databases and websites materials must be made easily accessible to the remote workers. It is now important and advisable for all organisations to have a policy on remote working written down.

The issue of public gathering and travelling has been restricted by the government and so is the same employers must comply by permitting those restrictions in their business and employees personal travels. If an employee travels to coronavirus affected area and wishes to return to work, the employer should ask the employee to stay away from work for the period of 14 days as self-quarantine. Should incase the company is to hold a meeting or any other form of gathering, then the following guidelines must be followed:

- Make it flexible by offering employees opt-out policy with no any consequences

- Wellness kits like fact sheet on the virus, sanitizers, tissues etc., must be made available to employees at the gathering.

- Voluntary participation by employees must be obtained in writing.

New HRM challenges may arise on a daily basis due to the continuous unprecedented national and state responses and reports on covid-19 pandemic. Further challenges presented by HR Daily Advisor Content Team (2020) stated that there must be a policy on office cleanliness and hand washing which can limit the spread of the coronavirus and the type industry or program will determine the circumstance. For example, child care, health care, and food preparation will all have different rules since industries are not the same. If employee is asked to stay away from work due to covid-19 pandemic will not be fair to count it as absenteeism. In this pandemic, an employ may be asked to stay home by the employer or as a mandatory requirement government as public health authority. Hence, it will be very difficult to terminate an employee contract based on absenteeism in such circumstance. It states legal considerations must be given such as Consolidated Omnibus Budget Reconciliation Act 
(COBRA) administration depends on notices that are sent within specified time periods, which are measured around the occurrence of an event that is qualified. For instance, an employer has its qualifying event to notify the plan administrator within 30 days period. According to Fair Labor Standards Act (FLSA) stated that employees on a personal journey and has been quarantined, the employee is not entitled to wages, no matter how the considerations regarding the exemption and non-exemption. However, the partial-day absence rules for employee exemption still apply. Paid time off is also applied when necessary and as appropriate and it can be deducted from business travels if the absence is not occasioned by the employer. But employer is liable if it occasioned by the travel. Also, according to the Internal Revenue Service (IRS) guidelines 2020, that healthcare benefits such as HighDeductible Health Plans (HDHP) may be treated and cover covid-19 testing without jeopardizing participants' eligibility for Health Savings Account (HAS). Health Insurance Portability and Accountability Act (HIPAA), can create nuisance for many sponsor plans as they measure the privacy rights of an employee or dependent who has contracted covid-19 which includes any deductions or cost sharing as stated by IRS. Basic requirements of HIPAA still apply even in a public health emergency, which is the most important thing to remember.

Occupational Safety and Health Acts (OSH Act) stated under its guidelines that, it is an obligation for employer to provide safe workplace. Worker Adjustment and Retraining Notification Act (WARN Act) provided that employers should keep in mind when they are to lay off workers due to loss of business during this covid-19. Advance notice is required by law to employers to provide them to employees in significant amount of time before layoffs. Unemployment benefits is also a major law that most states have a one week or seven (7) days waiting period to claim this benefit but some have waived it or are considering to waive it as it is a requirement to address covid-19 related cause of temporary furloughs/absenteeism/leave of absence.

Whistleblowing is another law that deals with employees who may refuse to report to work due to them being afraid of coronavirus exposure or contraction. But this will depend upon the nature of the exposure and potential risk. Worker's Compensation is also considered for example, getting flu whiles on a business trip is not covered by the worker's compensation simply because it can happen anywhere you can be not just on that business trip.

\section{How Information Technology can still grow HRM in new Practices}

Human Resource Management Practice by professionals is been disrupted by the coronavirus pandemic, which many companies have to resort to remote or home or virtual working. This actually caused managers to rethink about HRM Roles with the coronavirus pandemic. Lewis (2020) stated that in order for organisations to prevent the spread of the virus they switched to remote work model at a phenomenal level they never imagine. In this regard, the face-to-face contacts at work is being replaced with videoconferencing like zoom, and email which implies HR Managers are doing difficult jobs in difficult times. It is not only about the employees' health and safety or wellbeing that HR professional are worried about but also concern about processing of paperwork and provision of solace or comfort to the millions of employees who have lost their jobs or furloughed. HR Managers are striving day-in-day-out to keep employees who are still on the job productive, engaged and connected, and motivated, that is, all the factors that are related to the new norm. But what is clear is that most I.T. 
companies before the existence of covid-19 have been working remotely as part of their duties at work or employment. So, in that case, remote working is not all that new to most I.T companies.

Remote Working may become permanent (Lewis, 2020). That the number of organisations using telecommunication in the USA has increased up to $159 \%$ just between 2005 and 2017. The current data shows that about 4.7 million people in the USA are using telecommunication, which is an increase from 3.9 million in 2015. Information Technology companies are already remote workers at most, hence, no need to write more about them. The important aspect of HRM function in the use of Information Technology that is needed to manage and control the remote working are as follows:

Staff Attendance/Register-companies have to be robust with the kind of software and database they are using to monitor staff reporting to work remotely. This implies that time table of work schedules must be made available to staff via the online system adopted with proper training and awareness creation. Staff should be able to log-in and sign in at work and such data or register is captured for reference and processes.

Staff Performance - The online systems adopted by the companies should be able to check the performances and delivery of staff whiles they work remotely. Clear measures such as daily targets and reports of work done for the day or at all times based on schedule must be logged on to the system for appraisal purposes.

Coordination of Routine Work - It is important that the companies built in an integrated system that will check for daily patterns of work by staff whiles they work remotely in disperse manner. A robust system must be developed for the purpose of cross-checking staff work at all times.

Supervision - Supervisors have a great role to play in the efficiency and effectiveness of the entire staff work delivery according to responsibilities given. Hence, reporting system for supervisors' is eminent to help them to keep to staff attitude and character with their works.

Honesty and Truthfulness - Remote working gives an opportunity for staff to work by showing how honest and truth they are when there is no direct supervision or direct control from managers. Staff gets the chance to build on trust and integrity at work so that there will not be a question of low productivity. Honesty and truthfulness are the watch words when it comes to remote working. This means accurate reports and accounts of work must be reported without any discrepancies.

Leave of absence - Again, it is important for the online system to adopt a database that will capture leave of absence since staff is already working from home or remotely. This will make sure that staff do not abuse the remote working as a holiday from work and thereby not concentrating on their responsibilities. If staff is going to be off duty then that must be dully captured so that proper performance and responsibilities are measured accordingly.

\section{How Both National and International HRM Practice is Portrayed with Covid19}

As the covid-19 brought a lot of uncertainties in to the world of practices, especially, HRM responsibilities has been hit hard across the globe because it is about people management and that has been attacked by this pandemic. National and International practices have to change 
to suit the current phenomenon, so that, new ways of people management techniques will emerge to propagate the importance of HRM at workplaces. Deliotte (2020) reported on workforce strategies in this pandemic, which has been of the view that eminent crisis responds have to do with essential services, virtualization of education and work, and staff health and safety. The report saw three categories of the covid-19 pandemic which HRM leaders must note as recovering, thriving, and response $(R T R)$. Recovering in the sense that nations have to learn about this emerging pandemic more seriously, thriving to shape this new norm for all future workplace prosperity, and respond by dealing or tackling this covid-19 and manage its continuous distractions to work processes and responsibilities. The report indicated clearly that, HRM practitioners must now focus their attention towards the recovering in order to ensure that companies are prepared to thrive beyond this pandemic.

They are five (5) critical actions namely recommitment, re-engagement, reflection, rethinking, and rebooting the new norms that HRM leaders must reshape their focus on. Also, organisations must create multiple crises response scenarios as a plan within time frame to tackle these covid-19 distractions to work. Organisations must have plans to deal with the contraction of the pandemic which seem unlikely to end soon. Therefore, future planning is very important to help organisations to stay relevant and productive in this trying times of the coronavirus pandemic. For instance, it is recommended that HRM workbooks must be established in order to troubleshoot any problem that this pandemic pose to management of people process at work. Though, not all the questions can be addressed in the workbook as it will evolve around the covid-19 challenges.

In the Deloitte report, it indicated clearly what the workbook should look like as if the HRM leaders develop it as follows:

Within the work in particular the following must be developed as part of the plan to promote good work continuity. These are command centre, work design, travel, employment brand, software, hardware, digitization, analytics, community partnerships, regulatory and legal, vendor management, and a page for notes or remarks taking.

Within the workforce itself which determines the capabilities and affordability of the workforce has the following areas to be designed. These are scenario planning and alternative labour strategies, people strategy or operational plan, benefits plan, workforce experience, leadership, talent processes, and notes page.

Within the workplace the following are to be established, namely, health and safety, and workspaces, notes page.

According to Brown (2020) presented answers to key questions regarding overview of countries as follows:

In Brazil, it answers the question "what are an employer's main legal obligations?" The following are considered as the legal liability at workplace regarding coronavirus pandemic: -

- Providing healthy workplace

- Employees with symptoms must be asked to go for examination rather than the usual medical routine examination

- Only government can apply the measures and laws passed under the covid-19 laws 
Another question answered is "do I need to prepare for and have in place a workplace plans to deal with Covid-19?" That there is no law put in place against employers specifically, to have covid-19 preventive and response plans at workplace. Though, the Federal Government rather recommends to employers to have some contingency plan just in case there is any outbreak of covid-19 infections among employees. These measures should include quarantining individual affected with the infection, following hygiene protocols, use of masks mandatorily, and monitoring of employee health and safety to work by company physicians.

The third question that is been answered is "what should a workplace covid-19 response cover?" The ministry responsible in Brazil has issued guidelines regarding preventive measures against the covid-19 pandemic online. The other questions are:

- “can I direct my employees to go home or stay at home if there is an outbreak?" - Yes

- “can I direct an employee to see a doctor?" - Yes

- "do I have to continue to pay wages and provide other employment related entitlements during covid-19 outbreak?" - Not necessarily. The Brazilian government introduced many laws which enables employers to suspend employment contracts or agreements temporally and also to reduce employee workload, wages and among others.

- "can I quarantine certain staff to certain parts of an office or send them to a different office?" - Yes, for all and no discrimination.

- “can I direct my employees to report suspected cases of covid-19?" - There is no specific law in Brazil requiring employers to report suspected covid-19 cases. And appropriate measures already discussed can be applied.

- "can an employee lawfully refuse to attend work if there is a covid-19 outbreak?" Yes

- "can I screen employees and customers before allowing them to enter the workplace?" - No. Individual health data is considered sensitive.

In France, since $16^{\text {th }}$ April, 2020 an update on confinement was issued whereby some public places were shutdown, meeting involving more than 100 people was prohibited, traveling was restricted unless reasonable distance like home and work, buying food, health reason etc.

The following were the questions that was answered:

- “what are an employer's main legal obligations?" - Labour code and case law regarding workplace health and safety of employees must be followed. Pay employees accordingly, and companies must take health insurance as required by law.

- "do I need to prepare for and have in place a workplace plan to deal with covid19?" - companies are advised to setup a business continuity plan per the ISO requirement 2230:2019. Must have risk assessment document for regular updates.

- "what should a workplace covid-19 response plan cover?"-It must be a wider global like prevention plan and the French government has issue guidelines. 
- “can I direct my employees to go home or stay at home if there is an outbreak?" Yes, only when the employee is from infected area or is having symptoms. Remote work is recommended.

- "can I direct an employee to see a doctor?" - No. It relates to privacy.

- "do I have to continue to pay wages and provide other employment related entitlements during covid-19 outbreak?" - if it is by public authority (quarantine) for employee to stay home. Also, if the employer requires the employee to stay home, if employee decide to stay home, and if the employee provides sickness certificate.

- "can I quarantine certain staff to certain parts of an office or send them to a different office?" - employees returning from risky places or in contact with infected person, and employee having symptoms.

- "can I direct my employees to report suspected cases of covid-19?" - it is legitimate for employers to ask employees to report cases.

- “can an employee lawfully refuse to attend work if there is a covid-19 outbreak?" - employees have the right to refuse to work under the French Labour Code (right of withdrawal).

- "can I screen employees and customers before allowing them to enter the workplace?" - Yes, government has issued directive on fever-testing for people visiting their sites and should be an internal measure by notification.

In Germany, as at $5^{\text {th }}$ May, 2020 the following were the answers to the 10 questions:

- "what are an employer's main legal obligations?" - employers must take action to ensure health and safety at workplace: Health and Safety at Work Act, Infection Protection Act, contract of employment, the BGB and the virus acts and ordinances regarding the relationship between employer and employees.

- "do I need to prepare for and have in place a workplace plans to deal with covid19?" - no express legal obligation to employers in Germany to have covid-19 response plan, but all must ensure BGB. Employers can prepare detail plan.

- "what should a workplace covid-19 response plan cover?" - Must include all measures that will cure or mitigate the coronavirus pandemic.

- "can I direct my employees to go home or stay at home if there is an outbreak?" Yes, but it depends on the circumstance.

- "can I direct an employee to see a doctor?" - No. there is no general rights to this.

- "do I have to continue to pay wages and provide other employment related entitlements during covid-19 outbreak?" - Yes, as a general rule which an employer may recoup some of the benefits and compensations paid out.

- "can I quarantine certain staff to certain parts of an office or send them to a different office?" - Yes, but unless otherwise stated by the employer.

- “can I direct my employees to report suspected cases of covid-19?" - Yes, but it depends.

- "can an employee lawfully refuse to attend work if there is a covid-19 outbreak?" - Generally, No, but there may be exemptions to apply. 
- "can I screen employees and customers before allowing them to enter the workplace?" - unless the employees give their express consent.

In Hong Kong, as at $8^{\text {th }}$ April, 2020 the following were the answers to the 10 questions:

- “what are an employer's main legal obligations?" - ensuring health and safety, contract of employment terms must be complied with and the employment ordinance, complying with the Disability Discrimination Ordinance (ODD), complying with Personal Data (Privacy) Ordinance, and an employer may also review its employment policy.

- "do I need to prepare for and have in place a workplace plan to deal with covid19 ?" - No legal obligation in Hong Kong.

- "what should a workplace covid-19 response plan cover?" - Guidelines has been set out by the Centre for Health Protection, which advises on the prevention of severe respiratory disease associated with a novel infectious agent in workplace.

- "can I direct my employees to go home or stay at home if there is an outbreak?" Yes, but it depends.

- “can I direct an employee to see a doctor?" - Yes, butit depends.

- "do I have to continue to pay wages and provide other employment related entitlements during covid-19 outbreak?" - Yes, the employment contract will continue during the covid-19 pandemic.

- "can I quarantine certain staff to certain parts of an office or send them to a different office?" - it depends but it is also possible.

- “can I direct my employees to report suspected cases of covid-19?" - Yes.

- "can an employee lawfully refuse to attend work if there is a covid-19 outbreak?" - it depends but it is also possible.

- "can I screen employees and customers before allowing them to enter the workplace?" - Maybe, depending on the outbreak.

In the Kingdom of Saudi Arabia, as at $10^{\text {th }}$ April, 2020 the following 10 questions were answered accordingly:

- "what are an employer's main legal obligations?" - employers must always comply with the rules, regulations and laws of the Kingdom of Saudi Arabia. Saudi Ministry of Human Resource Management and other governmental ministries during this covid-19 pandemic issue frequent guidelines which must be adhered to.

- "do I need to prepare for and have in place a workplace plan to deal with covid19 ?" - There is no currently any formal requirement for workplace plan to be put in place. Employers are advised to following the pandemic guidelines and circulars.

- "what should a workplace covid-19 response plan cover?" - preventive measures such as cleanliness, protective items supplied, etc.

- "can I direct my employees to go home or stay at home if there is an outbreak?" All employees must now work remotely due to the 24-hour curfew imposed on the major cities. 
- “can I direct an employee to see a doctor?" - depending upon the circumstances, an employer may direct an employee to seek medical and safety clearance from a doctor before allowing him or her to enter the workplace.

- "do I have to continue to pay wages and provide other employment related entitlements during covid-19 outbreak?" - According to an issue on $6^{\text {th }}$ April, 2020 by the Saudi Ministry of Human Resources and Social Development for up to 6 months period, employer is permitted to give the following three (3) main options to employees. These are annual leave, unpaid leave, and renegotiating contract.

- "can I quarantine certain staff to certain parts of an office or send them to a different office?" - employers much follow the government circulars and with subject to the contract of agreement of employees.

- “can I direct my employees to report suspected cases of covid-19?" - Yes.

- "can an employee lawfully refuse to attend work if there is a covid-19 outbreak?" - Yes.

- "can I screen employees and customers before allowing them to enter the workplace?" - Yes.

In the United Arab Emirates, as at $3^{\text {rd }}$ April, 2020 the following are the answers:

- "what are an employer's main legal obligations?" - the Ministry of Human Resources and Emiratisation resolution no. 279 of 2020 was passed to support private sector business in UAE by allowing them to adopt certain measures during the pandemic. Redundancy cases are to be dealt with.

- "do I need to prepare for and have in place a workplace plan to deal with covid19 ?" - Yes, in the area of health and safety at work for all employees.

- "what should a workplace covid-19 response plan cover?" - the plan should cover the preventive measures, disinfecting the workplace at all times, awareness creation to everybody etc.

- "can I direct my employees to go home or stay at home if there is an outbreak?" question 1 answer is referred to.

- "can I direct an employee to see a doctor?" - depending upon the circumstance, yes, employer may require employees to obtain doctors clearance before they can enter the workplace.

- "do I have to continue to pay wages and provide other employment related entitlements during covid-19 outbreak?" - question 1 answer is referred to.

- "can I quarantine certain staff to certain parts of an office or send them to a different office?" - generally, yes, as it is reasonable.

- “can I direct my employees to report suspected cases of covid-19?" - Yes, under UAE federal Law No. (14) of 2014.

- “can an employee lawfully refuse to attend work if there is a covid-19 outbreak?" - Yes.

- "can I screen employees and customers before allowing them to enter the workplace?" - Yes.

In the United Kingdom, as at $29^{\text {th }}$ April, 2020 the following answers were provided for the 10 questions: 
- "what are an employer's main legal obligations?" - employers are subjected to several framework as obligations, some are in the common law, statute and regulations. And in the Europe, it includes the Health and Safety at Work Act 1974, European Council Directive 89/391, Coronavirus Act 2020 etc.

- "do I need to prepare for and have in place a workplace plan to deal with covid19?" - Every organization have plans in continuity but it will be good for them to review them in this pandemic or amend the existing and communicate that to employees.

- "what should a workplace covid-19 response plan cover?" - government guidelines must be studied and followed. Especially, the Action Point Checklist.

- "can I direct my employees to go home or stay at home if there is an outbreak?" It will very much depend on the individual contract.

- “can I direct an employee to see a doctor?" - stay at home guidelines must be followed as the current government guidelines encourages employees to work at home, if possible.

- "do I have to continue to pay wages and provide other employment related entitlements during covid-19 outbreak?" - government introduced the Coronavirus Job Retention Scheme, simply known as Furlough Scheme. Employers can apply for grants up to $80 \%$ of the employee regular wage or $£ 2500$ per month, whichever is the lowest.

- "can I quarantine certain staff to certain parts of an office or send them to a different office?" - key staff are identified with. Though employees may not contest this decision since it is pandemic.

- “can I direct my employees to report suspected cases of covid-19?" - Yes.

- "can an employee lawfully refuse to attend work if there is a covid-19 outbreak?" - this only applies to few skeletons of staff because the pandemic is already in session with restrictions.

- "can I screen employees and customers before allowing them to enter the workplace?" - Employers try to do this at workplace. The first legal issues are trickier. Also, human rights and civil liberties issues may start if such test is not available for staff to get tested. By and large, employers owe it a duty to apply reasonable care for employees at workplace.

In the United States, as at $20^{\text {th }}$ April, 2020 the following 10 questions were answered accordingly:

- “what are an employer's main legal obligations?" - this include health and safety at workplace, comply with applicable stay at home guidelines, comply with wage and hour obligations under fair Labor Standards Act together with other related states laws etc.

- "do I need to prepare for and have in place a workplace plan to deal with covid19?" - No specific legal obligation for employers in the US.

- "what should a workplace covid-19 response plan cover?" - Interim Guidelines for Businesses and Employers have been set out on preventive measures by the US Centers for Disease Control (CDC). 
- “can I direct my employees to go home or stay at home if there is an outbreak?" Yes, but any work from home policies must be complied with nondiscriminatory.

- “can I direct an employee to see a doctor?" - if the employee absent himself from work due to his own illness then the employer can require him to obtain doctors certificate before returning to work.

- "do I have to continue to pay wages and provide other employment related entitlements during covid-19 outbreak?" - It depends whether the business is subject to the FFCRA and any related emergency state and local laws, and/or the employee is working.

- "can I quarantine certain staff to certain parts of an office or send them to a different office?" - possibly.

- “can I direct my employees to report suspected cases of covid-19?" - Yes.

- "can an employee lawfully refuse to attend work if there is a covid-19 outbreak?" - Maybe.

- "can I screen employees and customers before allowing them to enter the workplace?" - Yes.

\section{The Case of HRM Practice in the Developing World with Covid-19}

In the report of Hazoume (2020) narrated an employee story about the pandemic where he lamented about the hardships that the lockdown brought to the people. Some of these hardships are that many of the people work in the informal sector, which is daily, where they have to go out and work in order to earn enough money to cater for the next day's food. Hence, the lockdown did not last and then the people started protesting for their livelihood and survival. This happened in many African countries where the lockdown was later ignored as people could not survive hunger. In Africa, many people work daily as hand to mouth and so confining them for a day or one week or months is something that could not sustain. This brought about fear of hunger and not fear of coronavirus, which is in contradiction to other international countries where there is better understanding of the circumstances and support are being provided to them. But same cannot be assured in African countries since governments always battles to even pay salaries without coronavirus pandemic and how more of given handouts or support to people. Such support has to come from somewhere outside the continent because Africa is poor and handicapped in many fronts of advancement.

In Ghana for instance, the government paid salaries upon the lock down and have secured support from the IMF which it used to provide support to some businesses that went in distress during the pandemic. But private sector or the informal sector have been hit with poor human resource management practice since business owners could not afford to pay their staffs as they normally do regularly because no business and no sales. Hence, employees were traumatized in general regarding the covid-19 pandemic as they were unsure if they can still go to the same employer. An employee feared that if the coronavirus pandemic had to spread in Africa like in Europe, America, and Asia, then the already poor nature of health systems in Africa has deteriorated more, it cannot match with the health systems in these advanced countries who are even struggling with the pandemic. In this pandemic case, an issue of double constraint has emerged because there are two pressures for employees to bear. The 
double constraint is a psychological akin to the term contradictory command or contradictory injunction (Hazoume, 2020). And these are paradoxical injunctions as they cannot be obeyed without disobeying and that is why it is termed double knot or double constraint. What these terms means is that it makes the employee feel as a loser even if they have a choice to make or decide, and whether they respond either way. This also implies as governments came up with restrictions and still go about economic businesses which is double and contradictory injunctions.

In this pandemic, majority of the people in Africa relied on their government regular updates with the covid-19. The HRM departments or practitioners are at a lost since they have to only repeat some of the guidelines that are been given by the governments. This is so because several Human Resource Developments said that the government never imposed any specific measures against the employers since they all comply with government lockdowns. Clearly, the HRM practice here is different to the practice in Europe, Asia and America.

Covid-19 and HR communication within multinational organisations operating in Africa are as follows:

- Awareness campaign intensively

- Work place distancing and postponement or cancellation of meetings and nonessential travels

- Provision of liquid soap daily to workers

- Daily temperature checking of staff at the entrance, that is, employers and customers

- Few staff working from home

- Payment of salaries in advance for staff needs like food supply

- Make internet connections available to some strategic homes of the company

- Mobile phone calls and data bundles monthly allowance/package increased substantially

- Provision of hygiene products to staff for their home use

- Provide money to prevent the contraction of the covid-19 for specific category of staff

Most staff developed the initiative to create WhatsApp groups in order to interact as workers and to deal with matters on daily basis. More importantly, they do meetings on free zoom software application to promote their work at a distance. It was also common that some form a hacking HR system in this pandemic to support their work. This Hacking HR simply means that a strategic function within an organisation creates synergies as an advantage of the technological transformation and digital systems. It is by way of improving their soft skills thereby promoting the human resources. There has been a recommended website as open source to reposition HR function for free (https://hackinghr.io/). The purpose of this website in 2020 is to be available in all major capital cities of the world, and this also includes the use of webinars. With this pandemic means that HRM professionals and practitioners have to be creative and one of the challenges with this pandemic is to make managers to appreciate that business continuity plan concept is strategically designed to protect the company human resources. So, if customers have taken a break is not a case that companies too must take a break and to be creating new process for the future. 
It is also stated that in Senegal some employees are been abused by their employers as they forced them to come to work without any safety protocols, this is all driven by fear of covid19 and panics. And that working from home is conceptual. Soy (2020) reported that many African countries have had very low spread of coronavirus and have been praised for that even though Africa has the fragile health system and practices. Below is the world graph on the coronavirus spread in accordance of the data:

Covid-19 cases compared by continent

Number of cases per day, seven-day rolling average

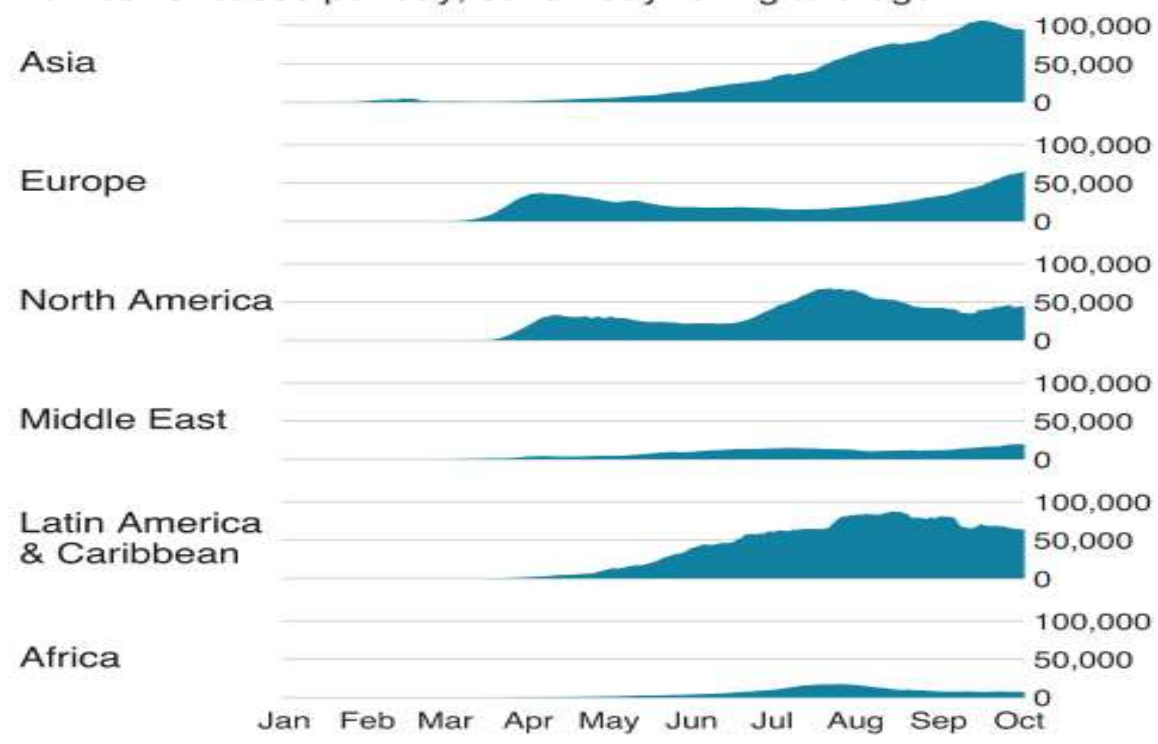

Oceania cases excluded as too low to register on scale

Source: ECDC and national public health agencies, data to 3 Oct $\quad$ BBIB]C

From the above graph it is clear that Africa has less than 50,000 cases per the description daily over seven days' period. Asia has the highest record cases daily per the graph above. Below chart also shows the compliance level Africans took towards the covid-19 pandemic.
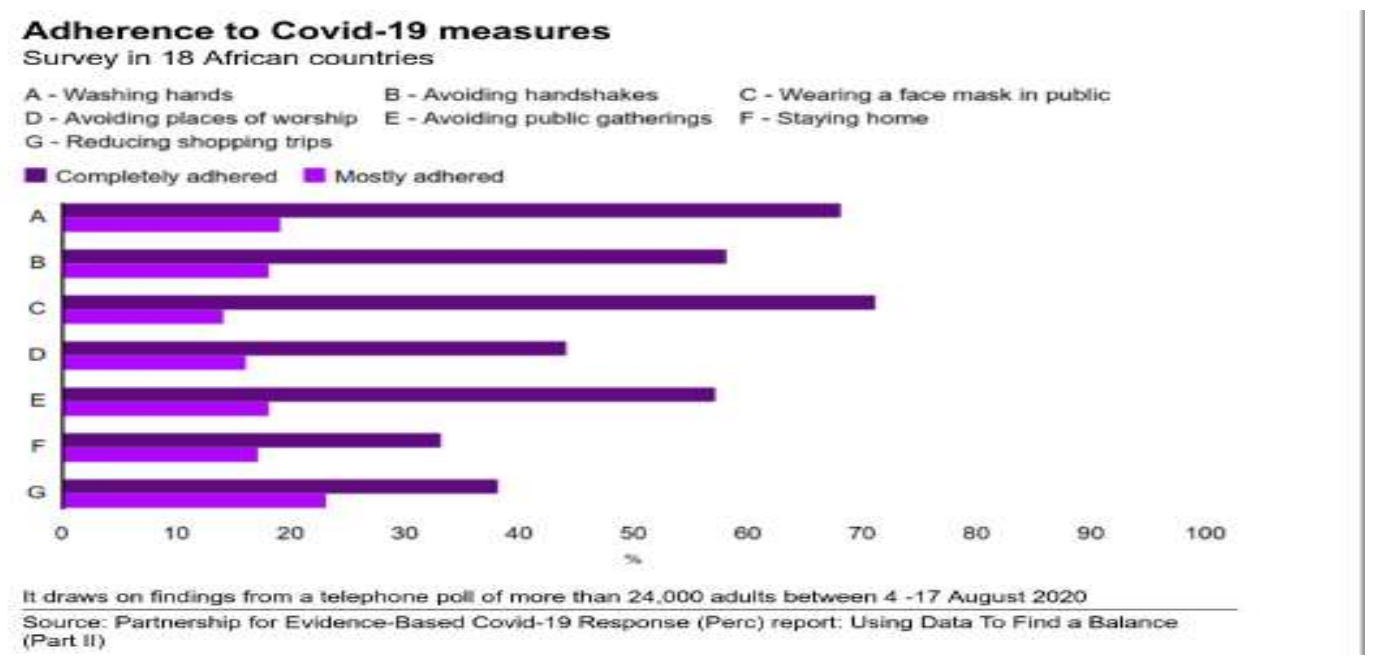

Published by: 
The following are the most reasons why African countries has very low level of covid-19 infections:

- Taking quick action

- Supported by the public

- Africa has young population and few old-age

- Favourable climate

- Community health or local systems are good and supportive

The World Bank (2020) press release stated that the growth in Sub-Saharan Africa will be affected due to the covid-19 pandemic from $2.4 \%$ to $-5.1 \%$ for 2019 and 2020 respectively over the past 25 years' recession. That the covid-19 has come to test the limits of economies and societies around the world. Though, the World Bank prediction of Africa to hit hard by this pandemic is yet to come to light because as it stands now Africa is the lowest affected continent. The World Bank stated that they are trying to support countries to be able to meet their health and survival needs and protecting jobs and safeguarding livelihood as the official bilateral debt services is called to remain standstill so that they can gather funds to help countries tackle this pandemic. It projected that Africa will face a cost between $\$ 37$ billion and \$79billion in output losses within 2020 based on combined factors.

Seun-Oguntuga and Olorunwaiye (2020) have submitted that ever since the coronavirus pandemic continue to devastate the world economies such as Nigeria and Africa as whole, many employers in both small and large companies are been troubled as to whether to cut down their staff or cut down the working hours or decide on redundancy. It is clear how this pandemic has disrupted and interrupted many organisations objectives through the government restrictions. In fact, both employers and employees suffered more in this covid19 pandemic unprecedently among Africa working class. Hence, new ways of delivering their responsibilities as stated in their contracts emerged across organisations, especially the private sector. The legislative instrument in Nigerian governing employment matters and contracts is the Labour Act 2004 and same in Ghana is Labour Act 2003. The other relevant legislations in Nigeria are:

- Trade Union Act

- Trade Disputes Act

- National Industrial Court Act

- National Industrial Court Rules, 2007

And in Ghana, there is:

- Trade Union Congress

- Workmen Compensations Act

- Companies Code

All the above legislations are being affected one way or the other since it has no direct laws and rules about this current covid-19 pandemic. This means that both the lawmakers and the employers will have to make new laws and rules to govern this current pandemic to protect people work and livelihood. During the lockdowns in Africa, most government supported their communities by sharing local cooked food to reduce hunger. Though, it had its own 
shortfalls but all the same majority appreciated the move since they could not come out to buy any food. Many also made it with politics to score political points.

Contracts between employers and employees are already bound and cannot be substantiated unless they both consent (Seun-Oguntuga and Olorunwaiye, 2020). Therefore, they tried to analyze the question what options are available to employers in relations to the contract of agreements already signed with employees, considering the impact of the covid-19 pandemic is putting their business through? Such as, in the case of NEPA vs Adesaaji where the court held that in the employer and employee relationship is governed by the terms and conditions of the contract they agreed upon, is causing paradoxical injunctions.

That, the new norm is Working from Home: there are many legal cases that backs this arrangement especially when cost or expenses is involved. In Nigeria courts, it is clear that foreign decisions or laws are only persuasive and are not binding on Nigeria laws. Hence, a case was ruled that employers have to reimburse employees working from home for any expenses they incurred during this covid-19 pandemic if they have not yet done so (such as in the case of Gattusovs Harte-Hanks Shoppers, Inc and in the case of AdetounOladeji (Nig.) Ltd. Vs N.B. Plc).

Reduction of Salaries/Wages or Deferment of Pay: This must be a win-win situation because it is clear how companies struggle to maintain or continue doing their business; hence, they may vary the terms and conditions of the contract either to reduce the remunerations or defer payments to an agreed dates and time. This is an option that employers can go for. This will enable the companies to be able to manage their resources and also, enable the employees to sustain their jobs. This is a fair suggestion to improve human resource management practice in this covid-19 pandemic like in the case of Adebusola Adedayo Omole vs Mainstreet Bank Microfinance Bank Ltd, where the court held that employers must not reduce employees pay without their consent. It is also established that at times an employee main continue to receive reduced salary without any written consent but continue to receive the reduced salary without any complain, like in the case of Oyeyemi vs Guardian Global Resources Nigeria Ltd, where the employee said there was no any written consent given but the court held that since he was silence and continue to receive it means that he consented.

Promotions and Bonuses Deferment: A clear case in this circumstance is the case of Toussaint vs Blue Cross and Blue Shield in Michigan where the Supreme Court held that when a promise in an employee handbook acquires legitimate expectation and the employer unlawfully breach or depart from it constitute a breach of contract. This has been applied in the Nigeria court in the case of Medical and Health Workers Union of Nigeria \&Orsvs Federal Ministry of Health. Where the court held that skipping salary grade level by government creates an expectation interest and return an entitlement or vested right in favour of the workers complaining who have been benefiting this all these while as a practice. But situations where the employer business is threatened then the court may reside with the employer as the realities may show. That promotions on the other hand are not contractual rights as it is a condition to be met by an employee just as in the case of Sylvester C. Nwoye vs Federal Airports Authority of Nigeria where the court held that promotion is not a right from one level or position to the other in an organization but a privilege earned and so 
therefore, an employer cannot be compelled to promote an employee no matter how good the person opinion is.

Unpaid and Paid Leave: In Nigeria, it contained in section 18 of the Labour Act 23 which provides that at least six (6) days of paid annual leave for every year of employment but most employment contracts have more than these 6 days of paid leave. Due to the covid-19 pandemic challenges where employees have to stay at home, it is suggested that employers may apply these 6 days as early as possible since the employees stay at home compulsorily. But the same cannot be applied to employees working from home. A case between AkinfemiwaAkinyinkavs More Time CO Gas Plant Ltd., where the court held that denial of annual leave to an employee was unfair practice of labour.

Redundancy: The labour laws in Nigeria has it that employers have the right to pay off any employee based on either idleness, redundancy, etc. Therefore, it defined redundancy as "involuntary and permanent loss of employment caused by an excess of manpower." And that no specific rules apply to collective redundancy or mass layoff. For instance, like in the case of Alexander O. Ejah \& Orsvs Niger Mills Co. Ltd., the court ruled that it was possible for the employer to have conducted mass redundancy because in this particular case that it was reasonable to do that since the company had changed from manual work to machine or technological application. Redundancy is a unique form based on procedures an employer use to quietly and lawfully relieve such employee from the post. It is not a by force resignation, it is not a dismissal, and it is not forced or voluntary retirement. Like in the case of OkwaraAgwu\&Ors vs Julius Berger Nigeria Plc., where the court held on the appeal ruling that the court will not compel an employer when they are unwilling to retain the staff but what they would do to order payment of all entitlement of the employees based on the contract terms and conditions.

Termination of Employment: This coronavirus pandemic can cause employers to terminate contracts of employment due to the realities of frustration and contractual force majeure. Change of circumstance can make it difficult for the contract to be performed, hence, termination. For instance, such changes may include outbreak of war, legal changes, cancellation by unexpected occurrence. Even the lockdowns in this covid-19 pandemic is also an example of change occurrence as frustrating event.

Resignation: Due to the covid-19 pandemic issues, an employee may choose to resign from work if he/she deem it fit and also the employer may reasonably advise an employee to resign due to the challenges it encounters.

In all these above, it would interest employers to reorganized the Strategic Human Resource Management to best explain its new policies in line of employee contract terms and condition. Job evaluations must be carried out by employers to ascertain the viable ones and then do away those that cannot be successful under this covid-19 pandemic. It is highly important for an employer to communicate all of its decisions to the employees for understanding.

Covid-19, according to Danquah et al., (2020) wrote on the experiences of employment and policy responses by developing countries within the Sub-Saharan African countries. They concluded that evidence showed negative effect of the coronavirus pandemic has affected largely at the informal sector workers who are in fact, the majority of the working poor class within the Suh-Saharan regions. The simple policies that the governments created within the 
Sub-Saharan regions are been disaggregated from transfer of the poor business to loans as substitute measure. As it is a know fact of the stagnant poverty situation in African countries, governments had no option but to introduce fiscal financial packages as stimulus to the businesses by application and assessment for qualification. The whole situation at the moment is cannot be quantified as to how bigger the effects are on employment and people livelihood. Even one cannot tell whether the support or stimulus financial packages that governments give to people and business actually solve the problem of losses. So, much is till expected to come as future situations of the covid-19 pandemic cases and problems emerged or eradicated. Below diagram shows the level of cases up to $22^{\text {nd }}$ June, 2020.

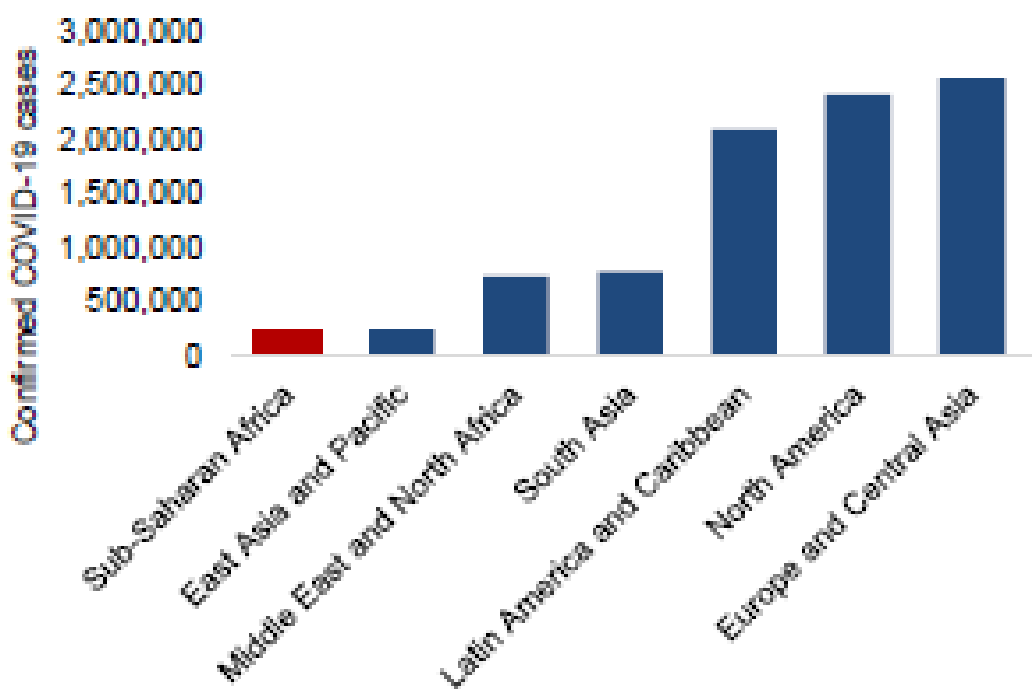

Source: Confirmed Covid-19 Cases in the world (Danquah et al., 2020).

The above diagram shows that Sub-Saharan African countries by then and up to date has very low cases of the covid-19 cases compared to other parts of the world. This may mean that the natural environment in Africa is good for protection or there is no much of such kind of diseases germinating from African soil.

The following were the support measures provided by the Ghana government (Danquah et al., 2020):

Government extended the filing of tax returns date to June instead the usual April. Reduce banks interest rates by $2 \%$ as at $1^{\text {st }}$ April, 2020. Banks granted a six-month moratorium toward the principal loan repayments to airline and the hospitality industries. Mobile money of an amount of GHs100 for free without charges. Government established Covid-19 fund managed by board of trustees. Three months tax holiday or heaven for health workers and GHs80 million for payment of special allowances. Government doubled the payment of Livelihood Empowerment against Poverty (LEAP) programme. Government absorbed water bills for three months and also absorb electricity bill for the poor, that is, life line consumers. Etc.

ILO (2020) stated that the crisis of covid-19 has already transformed shocks to the economy and labour markets. That the prospects for the quality and quantity of economy are 
deteriorating sharply. Aslo, that we need deeper policy and institutional reforms in order to strengthen demand-led recovery and improve robust build resilience and universal social protection systems to act as stabilizer of social and economic crisis. Below diagram shows the impact of the declining global growth on unemployment.

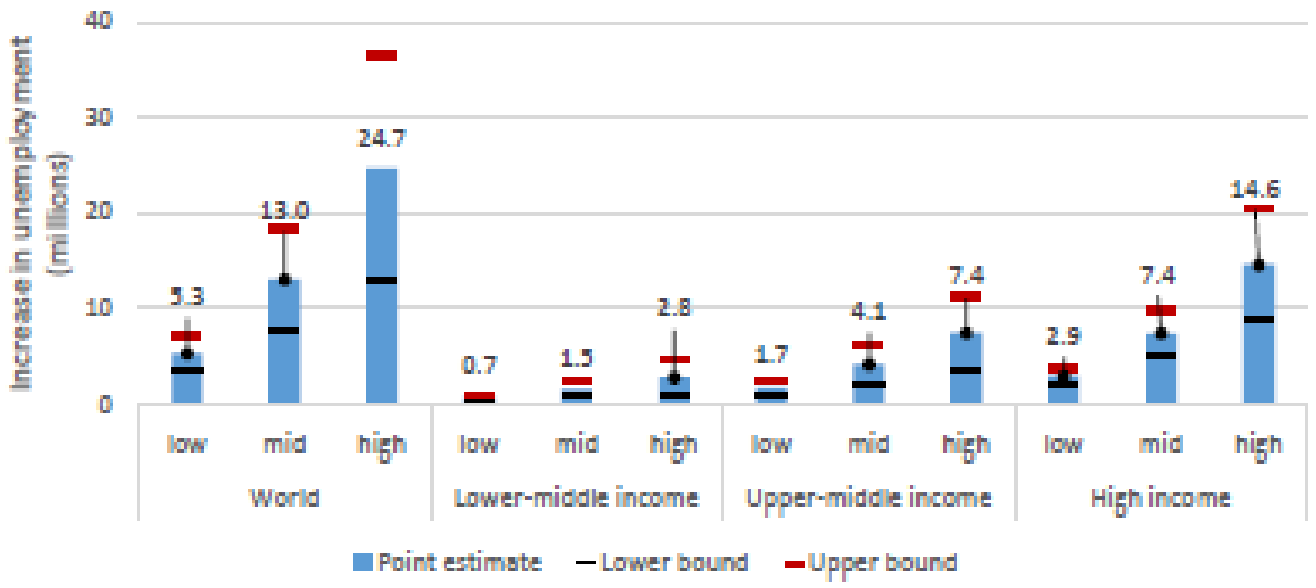

Source: Estimated Unemployment impact on three GDP growth Scenarios (ILO, 2020; McKibbin and Fernando, 2020)

The above diagram shows clearly that underemployment is expected to increase in great magnitude. Both services and manufacturing are highly impacted due to people movement as a decline in economic activity and constraints. Decline in Labour supply due to the quarantine measures and fall in economic activities. Below diagram shows estimated decline in Labour income and increase in moderate and extreme working poverty (i.e. less than $\$ 3.20$ per day, PPP, 2020).

\begin{tabular}{llll|}
\hline Incomegroup & Low & Mid & High \\
\hline Labour income (USs billion) & 860 & 4,720 & 3,440 \\
& & & \\
Extreme and moderate working poverty (millions) & & & \\
World & 8.8 & 20.1 & 35.0 \\
Low income & 12 & 2.9 & 5.0 \\
Lower middie income & 3.7 & 8.5 & 14.8 \\
Upper middle income & 3.6 & 8.3 & 14.5
\end{tabular}

Source: Working poverty estimates (ILO, 2020), This analysis excludes the potential impacts on working poverty in high-come countries. 
From the above diagram means that working poverty may increase significantly. The vulnerable people in this covid-19 pandemic are as follows:

- Those with health conditions and older people

- The youth already are unemployed and underemployed

- Inequality against women

- Unprotected workers like self-employed, casual and gig workers, and

- Migrant workers

The diagram below shows a policy framework on three key pillars on international Labour Standards:
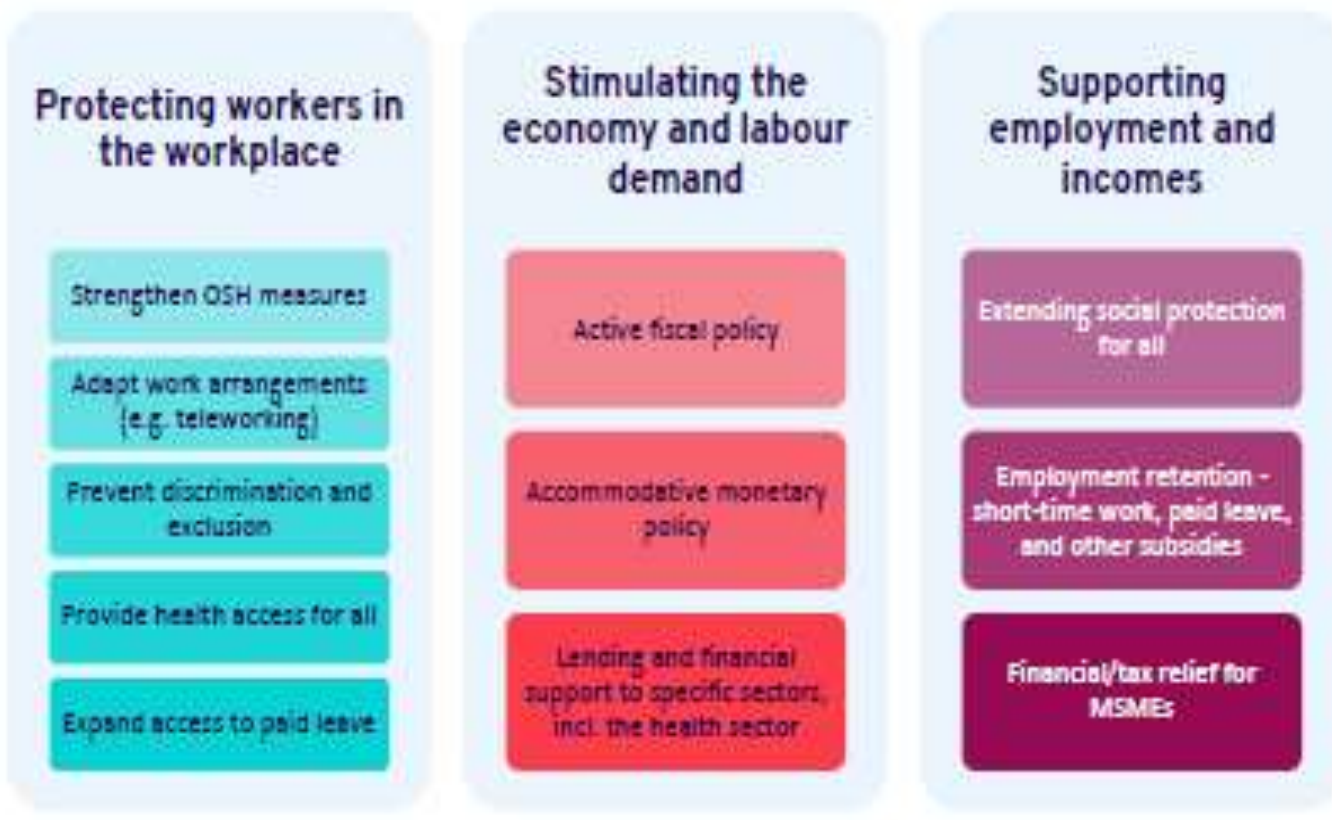

Source: Policy Framework (ILO, 2020)

\section{Method}

Basically, concept paper is defined in academic terms as a written paper with the main purpose of explaining and identifying an idea or a concept which relates to a particular scholarly discipline or field (authorassistant.com, 2020). And it is unbiased research that is written in a form of a theory or hypothesis by using impartial and relevant techniques in research.

By this definition above, when writing concept paper, methodology is not considered in population samples for quantitative and qualitative analysis since the concept idea is to propose and project hypothesis and gaps for future research quantitatively. Generally, concept papers in academic clarifies concepts, that is, by breaking or dissecting ideas into parts to give a collective explanation of those concepts. It also conveys the essence of an idea through explanation. And that is exactly the purpose of this paper title addresses. 


\section{Findings and Discussion}

The above review statements shows that HR Managers and professionals needs to be masters in remote work, thereby making good decisions as to taking most of the workforce remotely or not. Again, it is clear that HR Managers and Practitioners must be I.T. Savvy in order to give proper knowledge and support to staff working remotely. More so, People Management skills and policies needs to be rewritten as a new policy direction and requirement for recruitment. This pandemic has called for more training and development programmers for HR Managers and Professionals and Practitioners. Although the current picture of the covid19 is not conclusive and so more flexibility is needed by the HRM department at all times in order to conform to situations as they arise and changes and substitutes of decisions and policies well effected. The theoretical survey responses showed clearly that employees' attitude and behaviour has helped the situation within their work environment where they showed more empathy and compassion and willingness to collaborate and support each other for the achievement of same goals.

\section{Conclusion}

It is advisable that in this pandemic crisis that organizations and institutions to retrain their Human Resource Management Departments and the workforce in new advance areas of computer and internet technologies of software applications that can be introduced to enhance the remote work effectively in order to achieve same objectives. Again, new employment laws by a state are needed to effect the implementation of such laws in to policies for HRM practitioners. University curriculums must change with high technological implementation to facilitate online learning and education. It has been submitted that new contracts for staff or employees are eminent in line with the pandemic crisis hence, new pay structures and conditions of service can be redefined in the contracts. Motivation of employees is also paramount in this crisis, no undue pressures and threats against employees at this pandemic time but harmony is key in all sectors and corners of work. The most challenges that this review of the covid-19 concepts proposes are how the poorer countries in African can make gather accurate data and make it available for research and the world at large. It is also presumed that most international and foreign corporate business have relocated to the poorer countries in Africa and evade taxes by enjoying tax havens they negotiated to themselves. Hence, how can the current HRM practitioners in the African continent can help their working class and governments to also make sure that staff conditions of service and pay are higher in those international and foreign companies? By and large, the proposed HRM new functions suggested by Collington, (2020) must guide and direct all HRM practitioners work going forward. Hence, for future research, there is the need for quantitative study of this new Covid19 HRM practices in organisations and institutions for cross sectional analysis empirically.

\section{Reference}

Aitken-Fox, E., Coffey, J., Dayaram, K., Fitzgerald, S., Gupta, C., Mckenna, S., and Tian, A.W., (2020), The Impact of Covid-19 on Human Resource Management: Avoiding 
Generalisations, https://blogs.lse.ac.uk/businessreview/2020/05/22/the-impact-ofcovid-19-on-human-resource-management-avoiding-generalisations/ accessed: $10^{\text {th }}$ October, 2020.

Collington, M., (2020), The New Role for HR following the Covid-19 Pandemic, https://www.thehrdirector.com/features/cultural-change/the-new-role-for-hrfollowing-the-covid-19-pandemic/ $\quad$ accessed: $10^{\text {th }}$ October, 2020.

Wright, K.A., (2020), Human Resource Challenges in the Workplace Arising from the Coronavirus,Porzio Bromberg \& Newman PC, https://www.lexology.com/library/detail.aspx?g=f975dc63-94ea-4191-88a36e8f227fd4cc accessed: $10^{\text {th }}$ October, 2020.

HR Daily Advisor Content Team, (2020), Coronavirus (Covid-19), HR Management \& Compliance, Talent., https://hrdailyadvisor.blr.com/2020/03/20/covid-19-map-andresources-for-hr-professionals/ accessed: $10^{\text {th }}$ October, 2020.

Lewis, N., (2020), HR Managers Rethink Their Role During the Coronavirus Pandemic, https://www.shrm.org/hr-today/news/hr-news/pages/hr-managers-rethink-their-workcoronavirus-pandemic.aspx $\quad$ accessed: $10^{\text {th }}$ October, 2020.

Deloitte, (2020), Covid-19, Work Strategies for a Post-Covid-19 Recovery Workbook, Deloitte Design Studio, Canada, 20-6558T.

Brown, M., (2020), Managing HR Through Covid-19, A Practical Guide for Multinational Employers, Issue 7, Mayer Brown www.mayerbrown.com

Hazoume, Y., (2020), The HRD Front in Africa in the fight against Covid-19, Word of Experts https://yannhazoume.com/en/the-hrd-front-in-africa-in-the-fight-againstcovid-19-1/ accessed: $10^{\text {th }}$ October, 2020.

Soy, A., (2020), Coronavirus in Africa: Five reasons why Covid-19 has been less deadly than elsewhere, BBC, https://www.bbc.com/news/world-africa-54418613 accessed: $10^{\text {th }}$ October, 2020.

The World Bank (2020), Covid-19 (Coronavirus) Drives Sub-Saharan Africa Toward First Recession in 25 years, https://www.worldbank.org/en/news/pressrelease/2020/04/09/covid-19-coronavirus-drives-sub-saharan-africa-toward-firstrecession-in-25-years accessed: $10^{\text {th }}$ October, 2020.

Seun-Oguntuga, O., \&Olorunmaiye, J., (2020), Nigeria: The Impact of the Covid-19 Pandemic on Employment Contracts, https://www.mondaq.com/nigeria/employmentand-workforce-wellbeing/938130/the-impact-of-the-covid-19-pandemic-onemployment-contracts accessed: $21^{\text {st }}$ November, 2020.

Danquah, M., Schotte, S., \& Sen, K., (2020), Covid-19 and Employment: Insights form the Sub-Saharan African Experience, United Nations University, WIDER PROJECT

McKibbin, W., \&Fernando, R., (2020) The Global Macroeconomic Impacts of COVID-19: Seven Scenarios.

https://www.brookings.edu/research/the-global-macroeconomic-impacts-of-covid-19-sevenscenarios/ accessed: 05/12/2020 
ILO (International LabourOrganisation), (2020) Covid-19 and the World of Work: Impact and Policy responses, ILO Monitor $1^{\text {st }}$ Edition.

Authorassits.com (2020) How to write effective concept paper? https://www.authorassists.com/blog/how-to-write-an-effective-concept-paper/\# accessed: $31 / 10 / 2021$

\section{Copyrights}

Copyright for this article is retained by the author(s), with first publication rights granted to the journal.

This is an open-access article distributed under the terms and conditions of the Creative Commons Attribution license (http://creativecommons.org/licenses/by/4.0/) 